\title{
De arbeidsmarkt voor civiel-technisch opgeleiden 1995-2010
}

Citation for published version (APA):

Borghans, L., \& Matheeuwsen, A. (1995). De arbeidsmarkt voor civiel-technisch opgeleiden 1995-2010. Researchcentrum voor Onderwijs en Arbeidsmarkt, Faculteit der Economische Wetenschappen. ROA Reports No. 5 https://doi.org/10.26481/umarep.1995005

Document status and date:

Published: 01/01/1995

DOI:

10.26481/umarep.1995005

Document Version:

Publisher's PDF, also known as Version of record

\section{Please check the document version of this publication:}

- A submitted manuscript is the version of the article upon submission and before peer-review. There can be important differences between the submitted version and the official published version of record.

People interested in the research are advised to contact the author for the final version of the publication, or visit the DOI to the publisher's website.

- The final author version and the galley proof are versions of the publication after peer review.

- The final published version features the final layout of the paper including the volume, issue and page numbers.

Link to publication

\footnotetext{
General rights rights.

- You may freely distribute the URL identifying the publication in the public portal. please follow below link for the End User Agreement:

www.umlib.nl/taverne-license

Take down policy

If you believe that this document breaches copyright please contact us at:

repository@maastrichtuniversity.nl

providing details and we will investigate your claim.
}

Copyright and moral rights for the publications made accessible in the public portal are retained by the authors and/or other copyright owners and it is a condition of accessing publications that users recognise and abide by the legal requirements associated with these

- Users may download and print one copy of any publication from the public portal for the purpose of private study or research.

- You may not further distribute the material or use it for any profit-making activity or commercial gain

If the publication is distributed under the terms of Article $25 \mathrm{fa}$ of the Dutch Copyright Act, indicated by the "Taverne" license above, 


\title{
De arbeidsmarkt voor civiel-technisch opgeleiden
} 1995-2010

\author{
ROA-R-1995/5
}

Lex Borghans
Astrid Matheeuwsen

Researchcentrum voor Onderwijs en Arbeidsmarkt

Faculteit der Economische Wetenschappen en Bedrijfskunde Rijksuniversiteit Limburg

Maastricht, oktober 1995 


\section{CIP-GEGEVENS KONINKLIJKE BIBLIOTHEEK, DEN HAAG}

Borghans, Lex

De arbeidsmarkt voor civiel-technisch opgeleiden 1995-2010 / Lex Borghans, Astrid Matheeuwsen. - Maastricht: Researchcentrum voor Onderwijs en Arbeidsmarkt, Rijksuniversiteit Limburg, Faculteit der Economische Wetenschappen en Bedrijfskunde. - ([Rapport] / Researchcentrum voor Onderwijs en Arbeidsmarkt, ISSN 0922-8098; ROA-R-1995/5)

Met lit. opg.

ISBN 90-5321-162-4

Trefw.: arbeidsmarkt ; civiele techniek 


\section{Inhoudsopgave}

Blz.

1 Inleiding

2 Civiel-technisch opgeleiden op de arbeidsmarkt

3 Discrepanties op de arbeidsmarkt voor civiel-technisch opgeleiden

4 Arbeidsmarktspreiding

5 De salariëring van civiel-technisch opgeleiden

7 Vervangingsvraag 1995-2000

8 Het aanbod van schoolverlaters $1995-2000$

9 Vraag en aanbod $1995-2000$

10 Arbeidsmarktprognoses voor de periode $2000-2010$

11 Aanpassingsprocessen

12 Conclusies 


\section{Inleiding}

Zowel de werkgelegenheid als de investeringen in de bouw worden voor ongeveer $20 \%$ gevormd door de grond-, weg- en waterbouw (GWW). In deze sector vinden activiteiten plaats die gericht zijn op bouw, onderhoud en herstel van infrastructurele werken. De sector is sterk afhankelijk van de overheid. Veel infrastructurele werken worden immers geïnitieerd door de rijksoverheid, de lagere overheden of publiekrechtelijke organen. Voor een deel is de overheid rechtstreeks betrokken bij deze activiteiten en voor een deel fungeert zij als opdrachtgever. De activiteiten van de rijksoverheid in de GWW-sector vinden grotendeels plaats bij Rijkswaterstaat, dat deel uitmaakt van het Ministerie van Verkeer en Waterstaat (AMOA, 1995, Groot, 1995 en EIB, 1995).

Rijkswaterstaat is voor haar personeelsvoorziening sterk afhankelijk van de opleidingsrichting civiele techniek op zowel MBO-, HBO-, als WO-niveau. In totaal werken er bij Rijkswaterstaat ruim 3.000 mensen met een civiel-technische opleidingsachtergrond op deze niveaus. Het gaat hierbij bovendien om functies waarvoor het niet goed mogelijk is personen met een andere opleidingsachtergrond te recruteren.

Rijkswaterstaat is uiteraard niet de enige werkgever voor civiel-technisch opgeleiden. Op de arbeidsmarkt concurreert zij onder andere met andere overheidsorganen, aannemers en ingenieursbureaus die actief zijn in de GWW-sector. De laatste jaren zijn er signalen dat er knelpunten ontstaan in de personeelsvoorziening van civiel-technisch personeel. Zo constateren Ramaekers en Dekker (1993) reeds dat civiel- ingenieurs weinig moeite hebben met het vinden van werk. Corten en Nijman (1995, blz. 9) wijzen op 'een aanzienlijk potentieel aan opdrachten, die de komende jaren waarschijnlijk tot uitvoering zullen komen. De uitvoering hiervan kan echter onder druk komen staan door het optreden van knelpunten. Daarbij kan gedacht worden aan problemen in de personeelsvoorziening.'

Gezien het belang van civiel-technisch opgeleiden voor de organisatie, is Rijkswaterstaat met een project gestart om de positie van civiel-technisch personeel binnen de organisatie in kaart te brengen. Omdat de arbeidsmarktpositie van Rijkswaterstaat niet los gezien kan worden van de gehele arbeidsmarkt voor civieltechnisch opgeleiden, heeft de afdeling personeel van Rijkswaterstaat (Hoofddirectie) het Researchcentrum voor Onderwijs en Arbeidsmarkt (ROA) opdracht gegeven de verwachte arbeidsmarktontwikkelingen op middellange en lange termijn voor civiel-technisch opgeleiden te onderzoeken. In dit rapport worden de bevindingen van dit onderzoek beschreven. 


\section{Opbouw rapport}

In dit rapport worden prognoses voor de arbeidsmarktsituatie van civiel-technisch opgeleiden op zowel MBO-, HBO- als WO-niveau gegeven voor de periode 19952000 en voor de periode 2000-2010. Allereerst wordt echter ingegaan op de actuele arbeidsmarktsituatie. Op basis van gegevens uit de Enquête Beroepsbevolking van het Centraal Bureau voor de Statistiek (CBS, 1995) en een aantal meer toegespitste enquête-onderzoeken, wordt in hoofdstuk 2 een beeld gegeven van de aantallen werkenden met een civiel-technische opleiding, hun verdeling naar bijvoorbeeld geslacht en leeftijd, maar ook de aard van het bedrijf waar zij werken en de aard van hun functie. In hoofdstuk 3 worden de aansluitingsproblemen op de arbeidsmarkt van civiel-technisch opgeleiden besproken, aan de hand van gegevens over werkloosheid, onderbenutting en de aard van het dienstverband. In hoofdstuk 4 wordt ingegaan op de bedrijfssectoren en beroepen waarin zij werkzaam zijn. Hierdoor wordt een beeld verkregen van de spreiding van civieltechnisch opgeleiden over de arbeidsmarkt. In hoofdstuk 5 wordt vervolgens aandacht besteed aan de salariëring van civiel technici.

De hoofdstukken 6 tot en met 9 hebben betrekking op de perspectieven op de arbeidsmarkt voor de opleidingsrichtingen $\mathrm{MBO}, \mathrm{HBO}$ en WO civiele techniek voor de periode 1995-2000. Deze prognoses sluiten aan bij de recente prognoses voor De arbeidsmarkt naar opleiding en beroep tot 2000 (ROA, 1995a,b,c) uit het Informatiesysteem Onderwijs-Arbeidsmarkt. Dit heeft als voordeel dat de geschetste ontwikkelingen onderling consistent zijn. De prognoses geven een beeld van de arbeidsmarktperspectieven van opleidingen over de volle breedte van de arbeidsmarkt. Er worden 78 opleidingsrichtingen en 95 beroepsklassen onderscheiden. De prognoses voor de arbeidsmarktontwikkelingen naar opleiding en beroep zijn gebaseerd op de werkgelegenheidsprognoses naar bedrijfssector van het Centraal Planbureau (CPB, 1994, 1995). Uit deze werkgelegenheidsprognoses wordt op basis van een beroepenmodel de werkgelegenheidsontwikkeling per beroepsklasse voorspeld (Borghans en Heijke, 1994) en met behulp van een opleidingenmodel volgen hieruit werkgelegenheidsontwikkelingen per opleidingstype (Borghans en Heijke, 1993). Om specifiek de arbeidsmarktontwikkelingen voor civiel-technisch personeel te analyseren, zijn de genoemde prognoses echter te algemeen van aard. Hierin worden immers alle bouw-, civiel-technische en verwante opleidingen per niveau samengenomen in één opleidingstype. In hoofdstuk 6 wordt daarom de uitbreidingsvraag voor civiel-technisch opgeleiden verbijzonderd. Voor de verschillen in de ontwikkeling tussen de GWW-sector en de rest van de bouw-sector wordt gebruik gemaakt van prognoses van het Economisch Instituut voor de Bouwnijverheid (EIB, Aartman e.a., 1995). 
Naast de uitbreidingsvraag blijkt in het algemeen dat de vraag naar nieuwkomers die ontstaat door de arbeidsmarktuitstroom van vooral ouderen, een belangrijkere component van de vraag naar nieuwkomers vormt. In hoofdstuk 7 wordt ingegaan op deze vervangingsvraag. Ook deze prognoses zijn gebaseerd op voorspellingen uit het Informatiesysteem Onderwijs-Arbeidsmarkt, waarbij een verdere toespitsing op civiel-technisch opgeleiden heeft plaatsgevonden.

De uitbreidingsvraag en vervangingsvraag vormen te zamen de baanopeningen per opleidingstype. Tegenover deze baanopeningen staat het aanbod van nieuwkomers op de arbeidsmarkt. Voor de arbeidsmarkt voor civiel-technisch opgeleiden betreft dit naast het aan het begin van de prognoseperiode boven de markt zwevende aanbod van kortdurig werklozen, met name de arbeidsmarktinstroom van schoolverlaters. In hoofdstuk 8 wordt daarom een beeld gegeven van de instroom van schoolverlaters op de arbeidsmarkt. Deze prognoses zijn een verbijzondering van de Referentieraming 1995 van het Ministerie van Onderwijs, Cultuur en Wetenschappen (1995). De Referentieraming geeft een prognose van het aantal schoolverlaters vanuit het reguliere voltijd- en deeltijdonderwijs. Voor de arbeidsmarktinstroomprognoses die in dit rapport worden gepresenteerd, worden echter ook de effecten van het niet-reguliere onderwijs (waaronder het leerlingwezen) en de verschillende vormen van beroepsgerichte volwasseneneducatie meegenomen.

In hoofdstuk 9 worden de vraag naar en het aanbod van civiel-technisch opgeleiden tegenover elkaar gesteld. Dit leidt tot een indicatie voor mogelijke problemen in de personeelsvoorziening in de periode 1995-2000. Naast de genoemde elementen wordt bij deze confrontatie ook rekening gehouden met de zogenaamde substitutievraag. Door overschotten of tekorten bij verwante opleidingen kan ook de arbeidsmarktpositie van civiel-technisch opgeleiden worden beïnvloed. Dit betreft doorgaans de minder opleidingsspecifieke beroepen. Zo kan bijvoorbeeld een tekort aan programmeurs en systeemanalisten een extra aantrekkingskracht op civiel-technisch opgeleiden uitoefenen voor deze functies.

In hoofdstuk 10 worden de elementen van de arbeidsmarktpositie voor civiel-technisch opgeleiden (uitbreidingsvraag, vervangingsvraag, aanbod van schoolverlaters en hun confrontatie) voor de periode 2000-2010 geschetst. Voor de uitbreidingsvraag wordt hierbij aangesloten bij het Global-Shift-scenario uit Nederland in drievoud van het CPB (1992). In dit scenario wordt ervan uitgegaan dat er de komende tijd geen fundamentele beleidsveranderingen zullen plaatsvinden. Deze prognoses kunnen dan ook gezien worden als een basisscenario. Eveneens wordt kort ingegaan op de twee andere scenario's die worden onderscheiden in Nederland in drievroud. Vanwege de langere voorspelhorizon zijn deze prognoses uiteraard veel globaler van aard dan de prognoses voor de periode 1995-2000. 
Zeker in de GWW-sector, waar het overgrote deel van de werkzaamheden bestaat uit nieuwbouw, hangen de ontwikkelingen immers sterk af van het overheidsbeleid. Dit overheidsbeleid is uiteraard moeilijk nauwkeurig te voorspellen.

Om eventuele problemen in de personeelsvoorziening op te vangen is het van belang inzicht te hebben in de speelruimte die een eventuele aanpassing van het wervingsbeleid kan bieden. In hoofdstuk 11 wordt kort ingegaan op deze aanpassingsprocessen. Ten slotte wordt in hoofdstuk 12 een overzicht gegeven van de belangrijkste bevindingen uit het rapport voor de arbeidsmarktsituatie van civieltechnisch opgeleiden per opleidingsniveau.

\section{Databronnen}

In dit rapport wordt informatie bijeengebracht uit een uiteenlopend aantal databronnen. Ten eerste betreft dit de reeds genoemde Enquête Beroepsbevolking (EBB, CBS, 1995) van het CBS. Deze enquête geeft inzicht in de werkgelegenheid over de gehele werkzame beroepsbevolking. De vraagprognoses en actuele arbeidsmarktinformatie met betrekking tot de werkzame beroepsbevolking zijn gebaseerd op gegevens uit deze enquête. Om de robuustheid van de actuele informatie te vergroten, hebben de gepresenteerde gegevens telkens betrekking op het gemiddelde van de jaren 1993 en 1994. Om de herkenbaarheid van individuele respondenten te voorkomen, heeft het CBS restricties gesteld aan de publikatie van gegevens uit de EBB. Voor afzonderlijke jaren mogen alleen aantallen van minstens 5.000 personen en voor meerjaarsgemiddelden van minstens 2.500 personen gepubliceerd worden.

Naast de EBB is gebruik gemaakt van enkele meer specifiek gerichte enquêtes Voor de informatie over schoolverlaters betreft dit Registratie Uitstroom en Bestemming van Schoolverlaters (RUBS) voor het MBO (Van Smoorenburg en Van der Velden, 1995). Het moment van enquêteren ligt bij RUBS één jaar na afstuderen, bij de HBO-Monitor is dit ongeveer anderhalf jaar na afstuderen. Voor het HBO, de HBO-Monitor (Van de Loo, Hoevenberg en Van der Velden, 1995). Aan het presenteren van deze schoolverlatersinformatie is de restrictie gesteld dat de gepubliceerde gegevens per categorie minimaal betrekking moeten hebben op 25 respondenten. Informatie over afgestudeerden van de studierichting civiele techniek op WO-niveau komt van het enkele jaren geleden gehouden onderzoek door Ramaekers en Dekker (1993). De gegevens voor dit onderzoek zijn afkomstig van een enquête onder oud-studenten die in de periode 1986-1991 aan de Faculteit der Civiele Techniek van de TU Delft zijn afgestudeerd. Gegevens over de populatie TU-ingenieurs zijn afkomstig van de salaris-enquête van het Koninklijk Instituut van Ingenieurs (Klvl, 1992). Voor deze enquête is een disproportionele steekproef uit het ledenbestand van het KIvl benaderd. Ten slotte is, naast enkele 
incidentele bronnen gebruik gemaakt van het onderzoek naar de belangstelling van de jeugd voor techniek door Willems en De Grip (1993).

Door de grote diversiteit aan informatiebronnen sluiten de gehanteerde definities niet altijd volledig op elkaar aan. $\mathrm{Er}$ is echter geen databron beschikbaar die een algeheel beeld geeft voor de totale groep civiel-technisch opgeleiden. Naast informatie over civiel-technisch opgeleiden bevatten de tabellen in dit rapport ook gegevens over enkele andere studierichtingen. Deze opleidingen fungeren als referentiekader. In de meeste gevallen betreft dit bouwkunde en landmeetkunde, omdat deze opleidingen het meest verwant zijn aan civiele techniek, en de technisch opgeleiden op het desbetreffende opleidingsniveau in het algemeen. Ten slotte moet opgemerkt worden dat onder andere vanwege de reeds genoemde publikatiebeperkingen van het CBS en de schoolverlatersenquêtes bepaalde cijfers niet opgenomen kunnen worden. Deze ontbrekende getallen worden aangeduid met een punt. Als de typering of trend onbekend is, wordt dit aangeduid met een streepje (-). 


\section{Civiel-technisch opgeleiden op de arbeidsmarkt}

Zoals in de inleiding reeds werd opgemerkt, zijn er bij Rijkswaterstaat ruim 3.000 personen werkzaam met een opleiding civiele techniek op MBO-, HBO- of WOniveau. Tabel 2.1 toont dat op de gehele Nederlandse arbeidsmarkt 35.500 personen op deze niveaus een civiel-technische opleidingsachtergrond hebben ${ }^{1}$. Rijkswaterstaat heeft dus een aandeel op deze arbeidsmarkt van ruim $8,5 \%$. Hoewel dit een aanzienlijk marktaandeel is, betekent dit dat ook de ontwikkelingen bij andere bedrijven van grote invloed zijn op de personeelsvoorziening bij Rijkswaterstaat. Op MBO/LLW-niveau werkt iets meer dan $5 \%$ van het totale aantal werkenden met een civiel-technische opleidingsachtergrond bij Rijkswaterstaat. Op HBO-niveau is dit $9 \%$, terwijl dit op WO-niveau zelfs ruim $18 \%$ is.

Tabel 2.1

Aantal werkenden per opleidingsrichting, gemiddelde 1993-1994

\begin{tabular}{lrl}
\hline Opleidingsrichting & $\begin{array}{r}\text { aantal } \\
\text { werkenden }\end{array}$ & $\begin{array}{l}\text { trend } \\
1992-' 94\end{array}$ \\
\hline MBO/LLW civiele techniek & 16.500 & $\begin{array}{l}\text { dalend } \\
\text { stijgend } \\
\text { stijgend }\end{array}$ \\
MBO/LLW bouwkunde & 162.500 & constant \\
MBO landmeetkunde & 4.000 & - \\
MBO/LLW techniek & 700.000 & stijgend \\
HBO civiele techniek & 14.000 & stijgend \\
HBO bouwkunde & 18.500 & - \\
HBO landmeetkunde &. & - \\
HBO techniek & 120.500 & - \\
WO civiele techniek & 5.000 & - \\
WO bouwkunde & 12.000 & stijgend \\
WO geodesie & & $\cdot$ \\
WO techniek & 61.500 &
\end{tabular}

Bron: CBS/ROA

In de tabel zijn ter vergelijking per opleidingsniveau gegevens opgenomen over bouwkunde, landmeetkunde en techniek in het algemeen. De Enquête Beroepsbevolking van het $\mathrm{CBS}$, waar deze gegevens op gebaseerd zijn, maakt overigens geen onderscheid tussen MBO en leerlingwezen (LLW), zodat deze aantallen zijn samengenomen. De meeste civiel-technisch opgeleiden zijn te vinden op MBO- en

1. In de appendix wordt een overzicht gegeven van de opleidingen die tot civiele techniek worden gerekend. 
HBO-niveau, met respectievelijk 16.500 en 14.000 werkenden. Op WO-niveau zijn er slechts 5.000 civiel-technisch opgeleiden werkzaam.

Vergeleken met de opleiding bouwkunde en technisch opgeleiden in het algemeen is echter juist het aandeel van civiele techniek op MBO/LLW-niveau opmerkelijk laag. Er zijn ongeveer tien maal zoveel werkenden met de opleidingsachtergrond MBO/LLW bouwkunde dan met MBO/LLW civiele techniek. Van alle technisch opgeleiden op MBO/LLW-niveau heeft slechts $2,4 \%$ een civiel-technische opleidingsachtergrond. Op HBO-niveau is dit percentage $11,6 \%$ en op WO-niveau $8,1 \%$, zodat geconcludeerd kan worden dat civiel-technisch opgeleiden relatief hoog zijn opgeleid in vergelijking met andere technisch opgeleiden.

Tabel 2.2

Percentage mannen per opleidingsrichting, gemiddelde 1993-1994

\begin{tabular}{lrl}
\hline Opleidingsrichting & $\%$ & typering \\
\hline MBO/LLW civiele techniek & 100 & erg hoog \\
MBO/LLW bouwkunde & 99 & erg hoog \\
MBO landmeetkunde & 88 & hoog \\
MBO/LLW techniek & 94 & erg hoog \\
HBO civiele techniek & 96 & erg hoog \\
HBO bouwkunde & 95 & erg hoog \\
HBO landmeetkunde &. & erg hoog \\
HBO techniek & 97 & erg hoog \\
WO civiele techniek & 100 & erg hoog \\
WO bouwkunde & 92 & erg hoog \\
WO geodesie &. & gemiddeld \\
WO techniek & 93 & erg hoog \\
\hline
\end{tabular}

Bron: CBS/ROA

Tabel 2.2 geeft een overzicht van het aandeel mannen in het totaal aantal werkenden met de verschillende opleidingsachtergronden. De typering die hieraan wordt toegevoegd is gebaseerd op de relatieve positie van de opleiding ten opzichte van opleidingsrichtingen over de volle breedte van de arbeidsmarkt (zie ROA, 1995c). Afgezien van de landmeetkundige richtingen hebben alle genoemde technische opleidingsrichtingen een erg hoog percentage mannen. Op MBO/LLW- en WOniveau is het percentage mannen bij civiele techniek bovendien hoger dan het gemiddelde percentage bij alle technische opleidingen. Voor alle niveaus geldt dat het percentage mannen bij civiele techniek hoger is dan bij bouwkunde en landmeetkunde. 


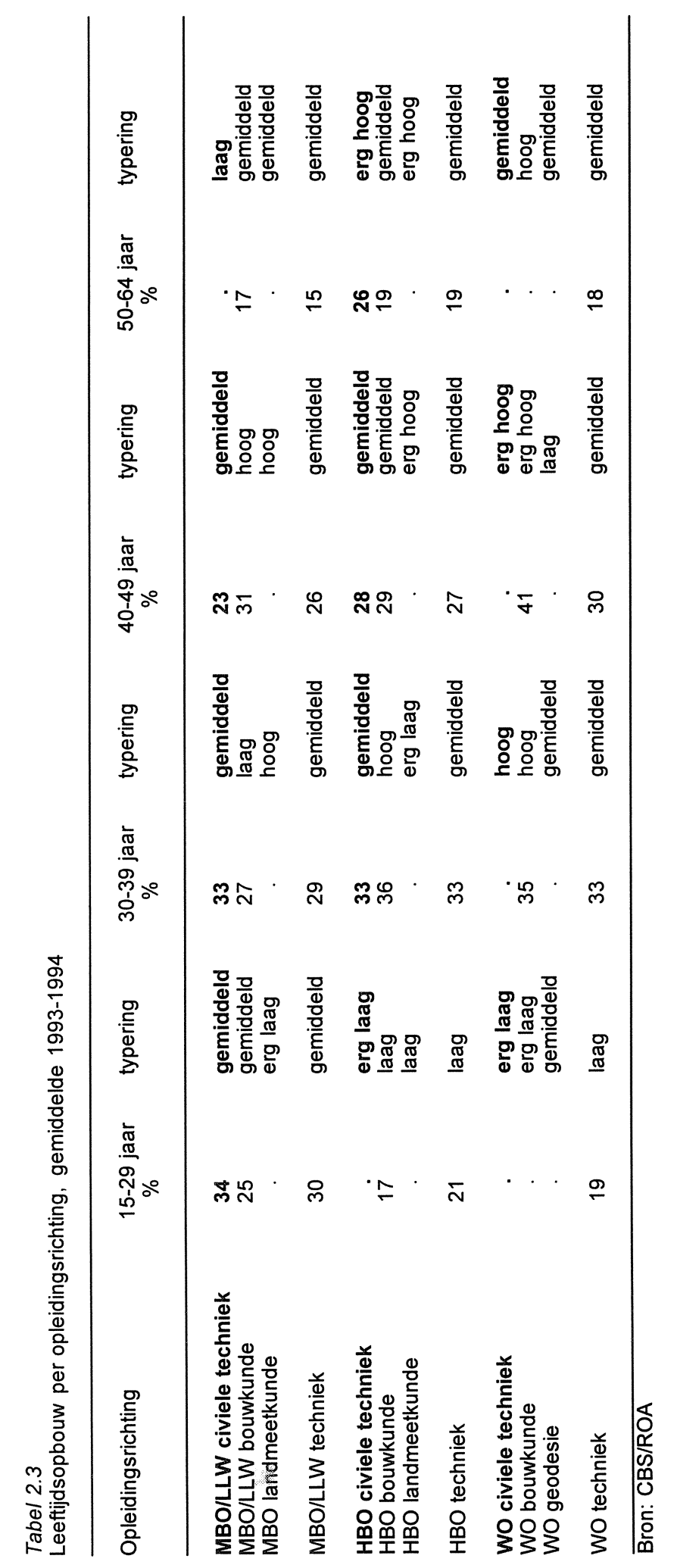


Tabel 2.3 gaat in op de leeftijdsopbouw van de werkzame beroepsbevolking met een civiel-technische opleiding. Als referentiegroep zijn bouwkunde, landmeetkunde en techniek in het algemeen opgenomen. Op MBO/LLW-niveau wijkt de leeftijdsopbouw van civiel technici alleen voor de groep 50-64 jaar af van de gemiddelde leeftijdsopbouw van alle technisch opgeleiden op dit niveau. Het aandeel van deze leeftijdsgroep is laag. Een mogelijke oorzaak hiervan is de vroege uitstroom van civiel-technisch opgeleiden als gevolg van VUT en seniorenregeling, maar vooral als gevolg van de uitstroom naar de WAO. Bij de werkenden met een MBO/LLW bouwkunde-opleiding is de leeftijdsgroep 30-39 jaar relatief ondervertegenwoordigd, terwijl er relatief veel werkenden tussen de 40 en 49 jaar zijn.

Op HBO-niveau is de leeftijdsopbouw van civiel-technisch opgeleiden sterker afwijkend van de gemiddelde leeftijdsopbouw van alle technisch opgeleide HBO'ers. Hier blijken de jongeren sterk ondervertegenwoordigd te zijn, terwijl het percentage werkenden met een leeftijd tussen 50 en 64 jaar erg hoog is. Kennelijk is er op HBO-niveau sprake van een vergrijzing van de civiel-technisch opgeleiden. Ook op WO-niveau zijn de jongeren uiteraard sterk ondervertegenwoordigd, maar hier is sprake van een hoog aandeel in de leeftijdsgroep 30-39 jaar en bevindt de top in de leeftijdsopbouw zich tussen de 40 en 49 jaar. Het aandeel van de werkenden boven de 50 jaar is gemiddeld.

Tabel 2.4 geeft de omvang van het bedrijf van werkenden met een opleiding civiele techniek en enkele (venwante) technische opleidingen. De gegevens zijn niet gebaseerd op de Enquête Beroepsbevolking, maar - voor wat betreft het $\mathrm{MBO}$ en het $\mathrm{HBO}$ - op de schoolverlatersenquêtes RUBS en HBO-Monitor, en - voor wat betreft het WO - op de salaris-enquête van het KIvI. Voor het MBO en HBO heeft de tabel dus alleen betrekking op schoolverlaters, terwijl voor het WO een beeld van nagenoeg de gehele beroepsbevolking (ledenbestand van het Klvl) wordt gegeven. Op alle niveaus blijkt het overgrote deel van de civiel-technisch opgeleiden werkzaam te zijn in een bedrijf met minstens 100 werkenden. Alleen op WO-niveau is nog een gemiddeld aandeel terug te vinden in het kleinbedrijf, op de andere niveaus werkt relatief een (erg) klein aandeel in het kleinbedrijf. Deels wordt dit verschil veroorzaakt door definitieverschillen, maar dit verschil kan ook voortkomen uit het feit dat met name civiel-technisch ingenieurs werkzaam zullen zijn bij advies- of ingenieursbureaus. Eveneens blijkt dat van de universitair geschoolde civiel technici die in een groot bedrijf werkzaam zijn, het overgrote deel werkzaam is in een bedrijf met een personeelsbestand tussen 100 en 500 personen of juist in een zeer groot bedrijf met meer dan 1.000 werkenden. 


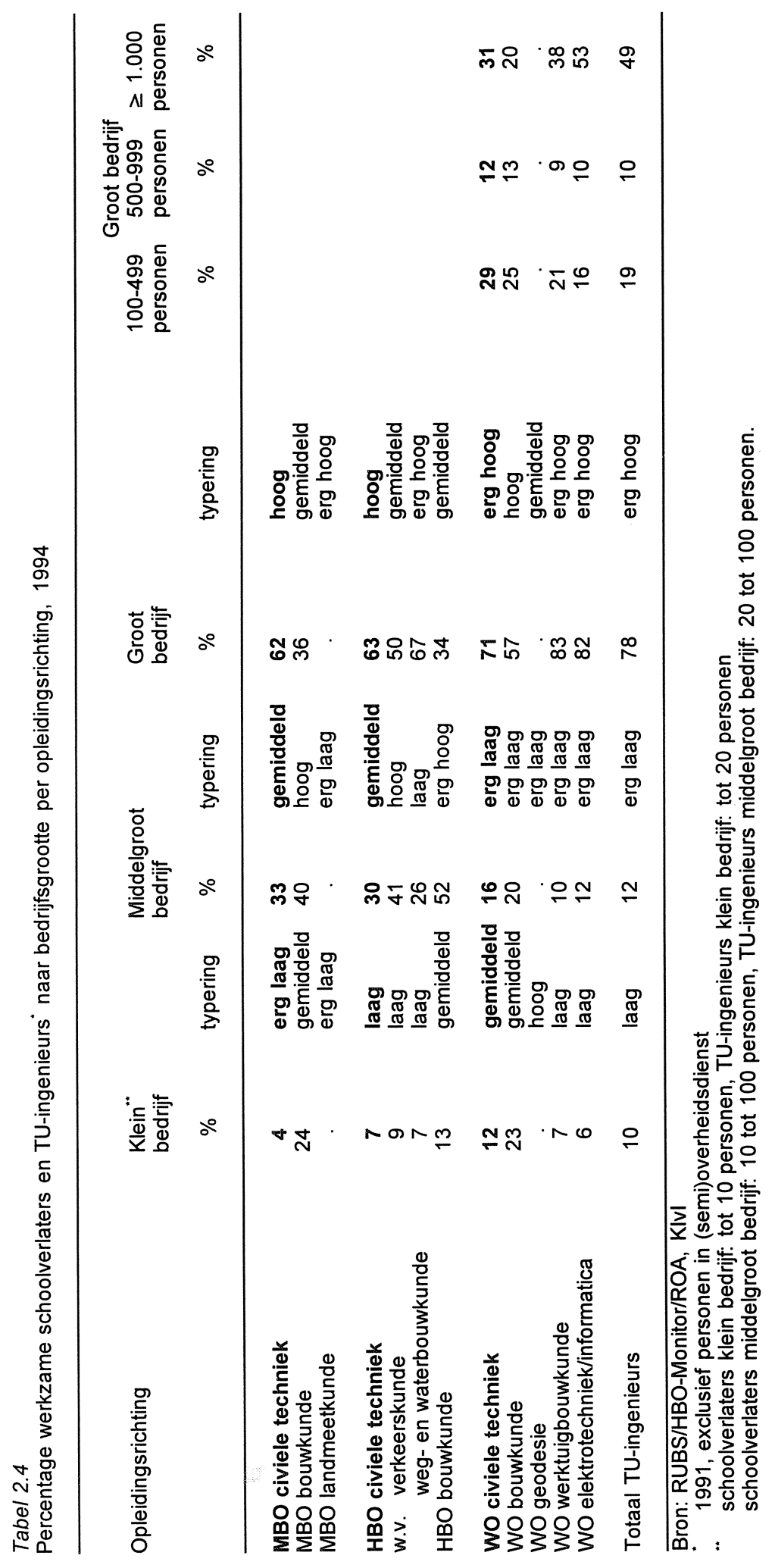


Tabel 2.5

Leidinggevende werkzame schoolverlaters en TU Delft civiel technici per opleidingsrichting, 1994

\begin{tabular}{lcl}
\hline Opleidingsrichting & $\%$ & typering \\
\hline MBO civiele techniek & 34 & erg hoog \\
MBO bouwkunde & 14 & gemiddeld \\
MBO landmeetkunde &. & erg laag \\
HBO civiele techniek & 21 & gemiddeld \\
w.V. verkeerskunde & 9 & erg hoog \\
weg- en waterbouwkunde & 25 & erg hoog \\
HBO bouwkunde & 29 & erg hoog \\
TU Delft civiele techniek & 47 &
\end{tabular}

Bron: RUBS/HBO-Monitor/ROA, TU Delft

najaar 1992

Zowel op MBO- als op HBO-niveau blijken relatief (erg) veel schoolverlaters van de opleiding civiele techniek als leidinggevende werkzaam te zijn. Dit wordt aangegeven in tabel 2.5. Op MBO-niveau contrasteert dit percentage sterk met het aantal schoolverlaters MBO bouwkunde dat in een leidinggevende functie terechtkomt. Van de civiel-technische opleidingen op HBO-niveau blijken met name de HBO'ers weg- en waterbouwkunde als leidinggevende werkzaam te zijn (25\%), terwijl van de verkeerskundigen slechts $9 \%$ een leidinggevende functie heeft. Op WO-niveau is zelfs bijna de helft van de civiel technici werkzaam als leidinggevende. Het betreft hier echter, zoals reeds eerder naar voren kwam, niet alleen recente schoolverlaters maar personen die zijn afgestudeerd in de periode oktober 1986 tot en met oktober 1991.

Tabel 2.6a

Zwaartepunt werkzaamheden TU-ingenieurs per opleidingsrichting, 1991

\begin{tabular}{lccc}
\hline Opleidingsrichting & $\begin{array}{c}\text { management } \\
\%\end{array}$ & $\begin{array}{c}\text { management } \\
\text { en vaktechnisch } \\
\%\end{array}$ & $\begin{array}{c}\text { vaktechnisch } \\
\end{array}$ \\
\hline WO civiele techniek & 32 & 39 & 28 \\
WO bouwkunde & 16 & 57 & 26 \\
WO geodesie & 30 & 38 & 31 \\
WO werktuigbouwkunde & 18 & 35 & 47 \\
WO elektrotechniek/informatica & 24 & 38 & 37 \\
Totaal TU-ingenieurs & & &
\end{tabular}

Bron: KIvl 


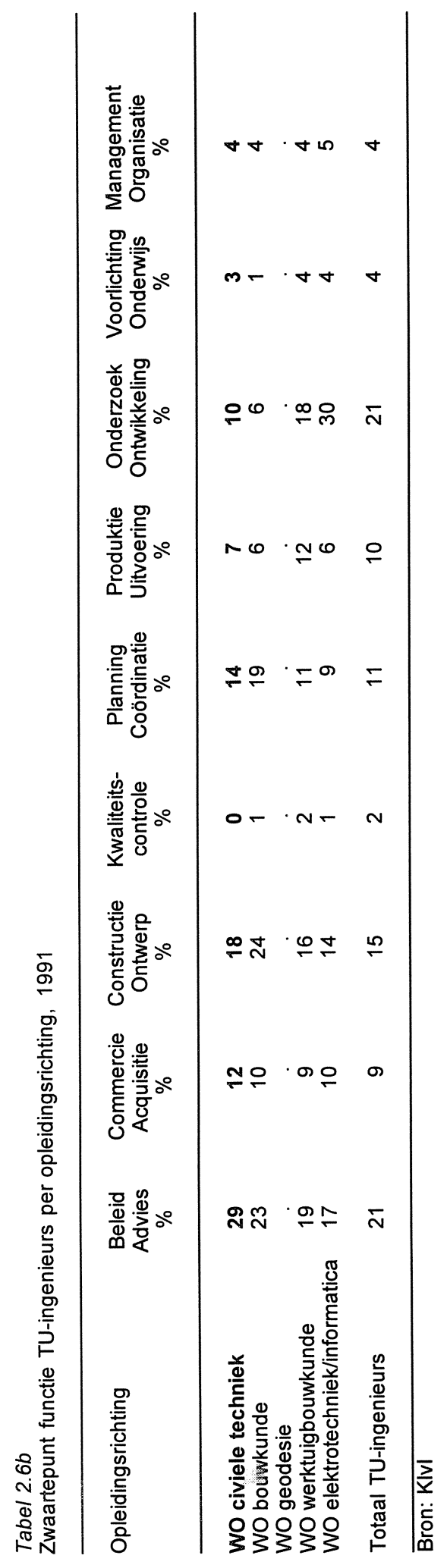


De gegevens omtrent de aard van het werk in de salaris-enquête van het Klvl verschillen enigszins van de gegevens die gepresenteerd zijn in tabel 2.5. Tabel 2.6a geeft daarom aan waar het functiezwaartepunt ligt van TU-ingenieurs. Het blijkt wederom dat op WO-niveau civiel-technisch opgeleiden vaker dan gemiddeld werkzaam zijn in een managementfunctie. Dit in tegenstelling tot bouwkundigen die vaker een managementtaak combineren met vaktechnische elementen en elektrotechnici en informatici die vaker dan gemiddeld een louter vaktechnische functie hebben.

Tabel 2.6b beschrijft het zwaartepunt van de functie van TU-ingenieurs vanuit een andere invalshoek. Werkenden met een opleiding WO civiele techniek blijken zich vaker dan gemiddeld bezig te houden met beleidsvoorbereiding en advieswerk, commercie en acquisitie, constructie en ontwerp en planning en coördinatie, terwijl zij zich minder dan gemiddeld bezighouden met produktie en uitvoering en onderzoek en ontwikkeling. De WO'ers bouwkunde geven eenzelfde beeld, waarbij zij zich opvallend veel bezighouden met constructie en ontwerp en juist opvallend weinig met onderzoek en ontwikkeling in vergelijking met het gemiddelde. De verdeling van het zwaartepunt van de functie van werktuigbouwkundigen, elektrotechnici en informatici op academisch niveau geeft hetzelfde beeld als de gemiddelde verdeling. Een uitzondering hierbij is dat de elektrotechnici en informatici zich opvallend veel bezig houden met onderzoek en ontwikkeling.

Hierbij worden commercie en acquisitie en planning en coördinatie meestal als managementtaken gezien, daarentegen zijn constructie en ontwerp en onderzoek en ontwerp doorgaans vaktechnisch van aard. Bij beleidsvoorbereiding en advieswerk ligt het zwaartepunt bij management, maar kent ook vaktechnische elementen. De overige in de tabel onderscheiden functiezwaartepunten zijn niet specifiek management of vaktechnisch van aard. Hoewel produktie en uitvoering en management, projectleiding en organisatie meer naar de managementkant neigen, terwijl kwaliteitscontrole en onderzoek en ontwikkeling iets vaker vaktechnisch zijn.

Tabel 2.7 geeft, tot slot van dit hoofdstuk, de verdeling van TU-ingenieurs over overheid, bedrijfsleven en zelfstandigen weer. Eén op de drie civiel-technisch ingenieurs werkt bij de (semi)overheid, terwijl dit voor TU-ingenieurs gemiddeld slechts $23 \%$ betreft. Civiel-technisch ingenieurs zijn derhalve minder vaak dan gemiddeld bij het bedrijfsleven werkzaam. Van de WO'ers bouwkunde is een veel groter percentage als zelfstandige werkzaam dan bij de civiel-ingenieurs. Evenals bij de civiel technici werkt ongeveer $60 \%$ van de bouwkundigen in het bedrijfsleven. Van de werktuigbouwkundigen, elektrotechnici en informatici werkt rond de driekwart bij het bedrijfsleven. 
Tabel 2.7

Verdeling TU-ingenieurs over overheid, bedrijfsleven en zelfstandigen per opleidingsrichting, 1991

\begin{tabular}{|c|c|c|c|}
\hline \multirow[b]{2}{*}{ Opleidingsrichting } & \multicolumn{2}{|c|}{ Loondienst } & \multirow{2}{*}{$\begin{array}{c}\text { zelfstandig } \\
\%\end{array}$} \\
\hline & $\begin{array}{l}\text { (semi)overheid } \\
\%\end{array}$ & $\begin{array}{c}\text { bedrijfsleven } \\
\%\end{array}$ & \\
\hline $\begin{array}{l}\text { WO civiele techniek } \\
\text { WO bouwkunde }\end{array}$ & $\begin{array}{l}32 \\
25\end{array}$ & $\begin{array}{l}60 \\
59\end{array}$ & $\begin{array}{r}7 \\
15\end{array}$ \\
\hline $\begin{array}{l}\text { WO werktuigbouwkunde } \\
\text { WO elektrotechniek/informatica }\end{array}$ & $\begin{array}{l}18 \\
23\end{array}$ & $\begin{array}{l}76 \\
72\end{array}$ & $\begin{array}{l}\dot{5} \\
4\end{array}$ \\
\hline Totaal TU-ingenieurs & 23 & 70 & 6 \\
\hline
\end{tabular}

Bron: KIvl 
........ 


\section{Discrepanties op de arbeidsmarkt voor civiel-tech- nisch opgeleiden}

Een eerste indruk met betrekking tot de vraag of er tekorten zijn aan civiel-technisch opgeleiden, wordt verkregen door te kijken naar de verhouding tussen de stromen van en naar de arbeidsmarkt. In dit hoofdstuk wordt ingegaan op enkele indicatoren met betrekking tot de actuele spanning tussen vraag en aanbod op de arbeidsmarkt voor civiel-technisch opgeleiden. Hierbij wordt achtereenvolgens ingegaan op werkloosheid en intrededuur, het verkrijgen van werk in de eigen vakrichting, onderbenutting, deeltijdwerk en de aard van het dienstverband.

Tabel 3.1a

Percentage schoolverlaters met een intredewerkloosheid van 4 maanden of langer per opleidingsrichting, 1994

\begin{tabular}{lrl}
\hline Opleidingsrichting & $\%$ & typering \\
\hline MBO civiele techniek & 13 & gemiddeld \\
MBO bouwkunde & 11 & laag \\
MBO landmeetkunde &. & laag \\
HBO civiele techniek & 13 & gemiddeld \\
w.v. verkeerskunde & 19 & gemiddeld \\
weg- en waterbouwkunde & 11 & laag \\
HBO bouwkunde & 8 & laag
\end{tabular}

Bron: RUBS/HBO-Monitor/ROA

Tabel 3.1b

Maatschappelijke positie TU Delft civiel technici na afstuderen per opleidingsrichting, najaar 1992

TU Delft civiele techniek

maand na afstuderen

Betaald werk

Student

Werkloos

Militaire/vervangende dienstplicht

Overig

$\begin{array}{rr}60 & 66 \\ 3 & 3 \\ 12 & 5 \\ 19 & 24 \\ 6 & 2\end{array}$

\section{Bron: TU Delft}

Tabel 3.1a en 3.1b geven een beeld van de intrededuur van schoolverlaters. Het gaat hier om de zogenaamde maatschappelijke positie, dat is de situatie zoals de geënquêteerden die zelf ervaren. De gegevens over afgestudeerden civiele techniek van de TU Delft zijn niet volledig vergelijkbaar met de gegevens over het MBO en HBO. Tabel 3.1a geeft voor de MBO'ers en HBO'ers aan hoeveel procent 
van de schoolverlaters na vier maanden nog werkloos is. Op MBO-niveau blijkt deze intredewerkloosheid voor civiel technici met $13 \%$ gemiddeld te zijn. Bij HBO civiele techniek als totaal ligt dit percentage ook op $13 \%$, maar dit wordt vooral veroorzaakt door de hogere intredewerkloosheid van $19 \%$ onder de verkeerskundigen. Voor weg- en waterbouwkunde is de intredewerkloosheid met $11 \%$ iets lager.

Tabel 3.1b geeft aan wat de maatschappelijke positie van de civiel-technisch opgeleiden van de TU Delft is drie en zes maanden na afstuderen. Van de afgestudeerden civiele techniek van de TU Delft blijkt na drie maanden nog $12 \%$ werkloos te zijn, terwijl na zes maanden de werkloosheid teruggelopen is tot $5 \%$. Ook deze cijfers lijken dus niet wezenlijk af te wijken van de intredewerkloosheid op MBO- en HBO-niveau. Na drie maanden heeft $60 \%$ van de civiel technici van de TU Delft betaald werk gevonden, na een half jaar stijgt dit percentage met slechts $6 \%$ tot $66 \%$.

Tabel 3.2

Percentage schoolverlaters en TU Delft civiel technici dat als werkloos staat geregistreerd per opleidingsrichting, 1994

\begin{tabular}{lrl}
\hline Opleidingsrichting & $\%$ & typering \\
\hline MBO civiele techniek & 5 & laag \\
MBO bouwkunde & 5 & laag \\
MBO landmeetkunde &. & - \\
HBO civiele techniek & 6 & laag \\
W.V. verkeerskunde & 11 & hoog \\
HBO bouwkunde & 5 & laag \\
& 3 & erg laag \\
TU Delft civiele techniek & 2 & erg laag
\end{tabular}

Bron: RUBS/HBO-Monitor/ROA, TU Delft

1 jaar na afstuderen, najaar 1992

Tabel 3.2 laat de werkloosheid onder schoolverlaters op het moment van enquêteren zien (voor het MBO en WO is dit één jaar na afstuderen, voor het HBO anderhalf jaar na afstuderen). In deze tabel gaat het om de 'officieel' geregistreerde werkloosheid. Op zowel MBO- als HBO-niveau is de werkloosheid onder civieltechnisch opgeleiden laag, respectievelijk 5 en 6\%. De verkeerskundigen binnen de opleidingsrichting HBO civiele techniek kennen echter een hoge werkloosheid van $11 \%$. Het werkloosheidspeil bij weg- en waterbouwkunde - de andere tak die wordt onderscheiden binnen de opleidingsrichting $\mathrm{HBO}$ civiele techniek - is dus laag. De werkloosheid onder deze groep is echter wel nog enigszins hoger dan de werkloosheid bij HBO bouwkunde. De geregistreerde werkloosheid voor afgestudeerden van de TU Delft is opvallend laag en bedraagt slechts $2 \%$. Dit kan er op 
wijzen dat met name op WO-niveau reeds sprake is van aanbodtekorten op de arbeidsmarkt.

Tabel 3.3

Werkloosheidspercentage onder hoger opgeleiden, 1993

Opleidingsrichting

HBO

Civiele techniek

Technische bedrijfskunde

Bouwkunde

Elektrotechniek

Hogere informatica

Werktuigbouwkunde

Nautisch

Laboratorium

Overig HTO

wo

Civiele techniek

Technische wiskunde

Technische informatica

Bouwkunde

Werktuigbouwkunde

Elektrotechniek

Technische scheikunde

Technische natuurkunde

Lucht- en ruimtevaart

Industriële vormgeving

Bron: Ministerie van Onderwijs en Wetenschappen/Van der Neut, Veldhoen en de Jonge, 1994

Vergelijkbare cijfers over werkloosheid volgen uit een onderzoek van Van der Neut, Veldhoen en De Jonge (1994). Via een telefonische enquête schatten zij de werkloosheidspercentages voor diverse onderwijsrichtingen op zowel HBO- als WO-niveau. Het betreft hier overigens de werkloosheid in 1993 onder alle afgestudeerden sinds 1978. De groep is dus aanmerkelijk breder dan alleen de schoolverlaters. Tabel 3.3 laat zien dat de werkloosheid bij civiele techniek op zowel HBOals WO-niveau zeer laag is. Op WO-niveau is het werkloosheidspercentage $0,9 \%$ en is er geen enkele andere technische opleidingsrichting met een lagere werkloosheid. De werkloosheid onder technisch opgeleiden is toch al opmerkelijk laag vergeleken met niet-technische opleidingsrichtingen. Over het gehele WO bezien blijkt alleen tandheelkunde een lager werkloosheidspercentage te vertonen. De meeste academische studierichtingen kennen een aanmerkelijk hogere werkloosheid. 
Ook op HBO-niveau ligt de werkloosheid onder civiel-technisch opgeleiden laag. Het werkloosheidspercentage is hier $1,1 \%$. Technische bedrijfskunde is de enige technische studierichting met een nog lagere werkloosheid. Ook op HBO-niveau zijn er buiten techniek slechts enkele richtingen te vinden met een nog lager werkloosheidspercentage. Deze ciffers wijzen er op dat niet alleen op WO-niveau, maar ook op HBO-niveau mogelijk momenteel reeds sprake is van een tekort aan civiel-technisch opgeleiden. Dit tekort uit zich kennelijk niet onmiddellijk na het afstuderen, maar vooral op de wat langere termijn, na ongeveer éen jaar. Deze trage start kan veroorzaakt worden doordat er vooral vraag is naar ervaren krachten, maar meer voor de hand ligt te veronderstellen dat vanwege het specifieke karakter van de GWW-sector, waarbij de werkgelegenheid sterk afhankelijk is van enkele opdrachtgevers en enkele projecten, de aansluiting tussen opleiding en arbeidsmarkt iets moeizamer verloopt. Ook het feit dat het hier gaat om een vrij klein, specialistisch segment van de arbeidsmarkt kan deze relatief moeizame start van schoolverlaters verklaren.

Tabel 3.4

Percentage werkzame schoolverlaters en TU Delft civiel technici met een functie in de eigen vakrichting per opleidingsrichting, 1994

\begin{tabular}{lcl}
\hline Opleidingsrichting & $\%$ & typering \\
\hline MBO civiele techniek & 77 & hoog \\
MBO bouwkunde & 79 & hoog \\
MBO landmeetkunde &. & hoog \\
HBO civiele techniek & 93 & erg hoog \\
w.V. verkeerskunde & 88 & hoog \\
$\quad$ weg- en waterbouwkunde & 95 & erg hoog \\
HBO bouwkunde & 92 & \\
TU Delft civiele techniek & & erg hoog \\
startfuncties & & hoog \\
latere functies & 91 & \\
\hline
\end{tabular}

Bron: RUBS/HBO-Monitor/ROA, TU Delft

najaar 1992

Discrepanties op de arbeidsmarkt komen niet alleen tot uitdrukking in werkloosheid, maar ook in de plaats waar iemand terecht komt op de arbeidsmarkt. Als er sprake is van overschotten, zullen mensen uitwijken naar functies buiten hun eigen vakrichting of beneden hun eigen opleidingsniveau. Tabel 3.4 laat zien hoeveel afgestudeerden een functie verwierven waarvoor hun eigen opleidingsrichting werd vereist. Voor alle genoemde opleidingsrichtingen is dit percentage hoog of erg hoog. Voor civiele techniek op HBO- en WO-niveau ligt dit percentage echter wederom beduidend hoger dan voor het MBO-niveau. Opmerkelijk is verder dat voor de Delftse civiel-ingenieurs juist bij startfuncties het percentage functies 
waarvoor de eigen opleidingsrichting vereist wordt, hoger is dan bij latere functies. Dit wijst erop dat de meeste afgestudeerden onmiddellijk binnen hun eigen vakgebied terecht komen en niet uit hoeven te wijken naar andere vakgebieden. Pas later in hun loopbaan blijken zij voor een deel dit vakgebied te verlaten, waarschijnlijk vooral doordat ze vaker in beleids- of managementfuncties terecht komen, waarbij de band tussen opleiding en beroep minder sterk zal zijn.

Tabel 3.5

Onderbenutting van werkzame schoolverlaters en TU Delft civiel technici per opleidingsrichting, 1994

\begin{tabular}{lcl}
\hline Opleidingsrichting & $\%$ & typering \\
\hline MBO civiele techniek & 6 & erg laag \\
MBO bouwkunde & 25 & gemiddeld \\
MBO landmeetkunde &. & laag \\
HBO civiele techniek & 5 & erg laag \\
w.V. verkeerskunde & 6 & erg laag \\
$\quad$ weg- en waterbouwkunde & 5 & erg laag \\
HBO bouwkunde & 11 & laag \\
TU Delft civiele techniek & & \\
startfuncties & 19 & gemiddeld \\
latere functies & 13 & laag \\
\hline
\end{tabular}

Bron: RUBS/HBO-Monitor/ROA, TU Delft

najaar 1992

In tabel 3.5 wordt bekeken in hoeverre afgestudeerden werk vinden beneden hun opleidingsniveau. Men spreekt dan van onderbenutting. Het blijkt dat voor MBO en HBO civiele techniek deze onderbenutting erg laag is. Op WO-niveau blijkt echter $19 \%$ van de afgestudeerden een startfunctie beneden het academische niveau te verwerven. Bij latere functies zakt dit percentage tot $13 \%$. De lage werkloosheid bij WO civiele techniek, blijkt derhalve samen te gaan met enige onderbenutting. Omdat het niet voor de hand ligt te veronderstellen dat deze onderbenutting voortkomt uit een overschot aan civiel-technisch ingenieurs, kan dit er op wijzen dat voor civiel-technische functies steeds hogere kwalificatie-eisen worden gesteld. Hierdoor worden voor functies die vroeger veelal door HBO'ers werden vervuld, thans steeds vaker WO'ers geworven. Het ROA (1995a) toont dat dergelijke verschuivingen tussen niveaus, binnen de technische richtingen vooral plaatsvinden tussen WO en HBO enerzijds en tussen MBO en VBO anderzijds. De verschuiving van functies van MBO naar HBO blijkt, bij de technische beroepen, minder vaak voor te komen. 
Tabel 3.6a

Voltijdarbeid onder werkzame schoolverlaters en TU Delft civiel technici per opleidingsrichting, 1994

\begin{tabular}{lcl}
\hline Opleidingsrichting & $\%$ & typering \\
\hline MBO civiele techniek & 91 & hoog \\
MBO bouwkunde & 94 & erg hoog \\
MBO landmeetkunde & $\cdot$ & - \\
HBO civiele techniek & 97 & erg hoog \\
W.V. verkeerskunde & 94 & erg hoog \\
HBO bouwkunde & 98 & erg hoog \\
TU Delft civiele techniek & 89 & hoog
\end{tabular}

Bron: RUBS/HBO-Monitor/ROA, TU Delft

najaar 1992

Tabel $3.6 b$

Voltijdarbeid per opleidingsrichting, gemiddelde 1993-1994

\begin{tabular}{lcl}
\hline Opleidingsrichting & $\%$ & typering \\
\hline MBO/LLW civiele techniek & 95 & hoog \\
MBO/LLW bouwkunde & 96 & erg hoog \\
MBO landmeetkunde & 90 & hoog \\
HBO civiele techniek & 97 & erg hoog \\
HBO bouwkunde & 94 & hoog \\
HBO landmeetkunde &. & erg hoog \\
WO civiele techniek & 94 & hoog \\
WO bouwkunde & 89 & hoog \\
WO geodesie &. & erg hoog \\
\hline
\end{tabular}

\section{Bron: CBS/ROA}

In tabel 3.6a en 3.6b wordt ingegaan op het percentage civiel-technisch opgeleiden dat een voltijdbaan heeft. Als het moeilijker is om een baan te verwerven, blijken mensen vaker dan normaal een deeltijdbaan te accepteren. Een deeltijdbaan kan echter natuurlijk ook een duidelijke keuze van iemand zijn. Tabel 3.6a geeft informatie over voltijdarbeid bij schoolverlaters, terwijl $3.6 \mathrm{~b}$ dezelfde informatie voor de gehele werkzame beroepsbevolking verstrekt. Voor al de gepresenteerde richtingen blijkt het percentage werkenden met een voltijdbaan hoog of zeer hoog te zijn. De hoogste percentages worden aangetroffen bij HBO civiele techniek. Zowel over de werkzame beroepsbevolking als geheel, als onder de schoolverlaters bezien, ligt dit percentage dicht tegen de $100 \%$. 
Tabel 3.7a

Percentage werkzame schoolverlaters en TU Delft civiel technici met een vast dienstverband per opleidingsrichting, 1994

\begin{tabular}{lcl}
\hline Opleidingsrichting & $\%$ & typering \\
\hline MBO civiele techniek & 68 & hoog \\
MBO bouwkunde & 64 & hoog \\
MBO landmeetkunde &. & erg laag \\
& 53 & gemiddeld \\
HBO civiele techniek & 50 & gemiddeld \\
W.V. verkeerskunde & 54 & gemiddeld \\
weg- en waterbouwkunde & 62 & ergiddeld \\
HBO bouwkunde & 80 & \\
TU Delft civiele techniek & &
\end{tabular}

Bron: RUBS/HBO-Monitor/ROA, TU Delft

in loondienst, najaar 1992

Tabel 3.7b

Percentage werknemers met vast werk per opleidingsrichting, gemiddelde 1993-1994

\begin{tabular}{lcl}
\hline Opleidingsrichting & $\%$ & typering \\
\hline MBO/LLW civiele techniek & 93 & gemiddeld \\
MBO/LLW bouwkunde & 97 & hoog \\
MBO landmeetkunde & 99 & erg hoog \\
& 97 & hoog \\
HBO civiele techniek & 98 & hoog \\
HBO bouwkunde &. & erg hoog \\
HBO landmeetkunde & 97 & hoog \\
WO civiele techniek & 96 & hoog \\
WO bouwkunde &. & hoog \\
WO geodesie & & \\
\hline
\end{tabular}

\section{Bron: CBS/ROA}

Tabel 3.7a en 3.7b geven vergelijkbare informatie voor schoolverlaters en de gehele werkzame beroepsbevolking met betrekking tot de aard van het dienstverband. Op HBO-niveau blijkt slechts ongeveer de helft van de schoolverlaters een vaste baan te verwerven. Bij het MBO ligt dit percentage voor civiele techniek op $68 \%$, en bij het WO heeft maar liefst $80 \%$ van de afgestudeerden een vaste baan. Zij het dat het bij het WO, zoals reeds werd opgemerkt, niet alleen om recente schoolverlaters gaat, maar om afgestudeerden vanaf oktober 1986 tot en met oktober 1991. Tijdelijke banen blijken echter vooral voor schoolverlaters relevant te zijn. Tabel 3.7b toont dat onder de gehele werkzame beroepsbevolking vrijwel iedereen een vast dienstverband heeft. Landmeetkunde scoort echter op alle niveaus hoger dan civiele techniek. Verder is voor civiele techniek op MBO/LLW- 
niveau het percentage vaste banen iets lager dan op HBO- en WO-niveau. Dit kan, evenals het feit dat de civiel-technisch opgeleide schoolverlaters op MBO/LLWniveau in vergelijking met het $\mathrm{HBO}$ en WO vaker buiten de eigen vakrichting werk vinden en een deeltijdbaan hebben, er op duiden dat op MBO/LLW-niveau de positie van civiel-technisch personeel enigszins zwakker is dan op HBO- en WOniveau. 


\section{Arbeidsmarktspreiding}

Hoewel de opleidingen voor civiele techniek duidelijk gericht zijn op technische werkzaamheden in de GWW-sector, komen lang niet alle civiel-technisch opgeleiden hier terecht. Net als bij andere technische opleidingen vindt een groot deel werk in een niet-technisch beroep. Recent onderzoek (Borghans, De Grip en Smits, 1995) laat zien dat $40 \%$ van alle technisch opgeleiden in een niet-technisch beroep werkt. Voor civiele techniek blijken deze percentages overigens lager te liggen. Op MBO/LLW-niveau werkt gemiddeld 33\% van de technisch opgeleiden buiten de techniek; voor weg- en waterbouwkunde (inclusief landmeetkunde) is dit $27 \%$. Op HBO-niveau werkt $46 \%$ van de technisch opgeleiden buiten de techniek; bij (weg- en water)bouwkunde (inclusief landmeetkunde) blijft dit beperkt tot $28 \%$. Op het WO-niveau, ten slotte, is maar liefst $54 \%$ van de technisch opgeleiden (inclusief wiskundigen en natuunwetenschappers van de niet-technische universiteiten) werkzaam buiten de techniek; bij bouwkunde/civiele techniek (inclusief geodesie) is dit $30 \%$.

Tabel 4.1

Belangrijkste beroepsklassen per opleidingsrichting, gemiddelde 1993-1994

Opleidingsrichting

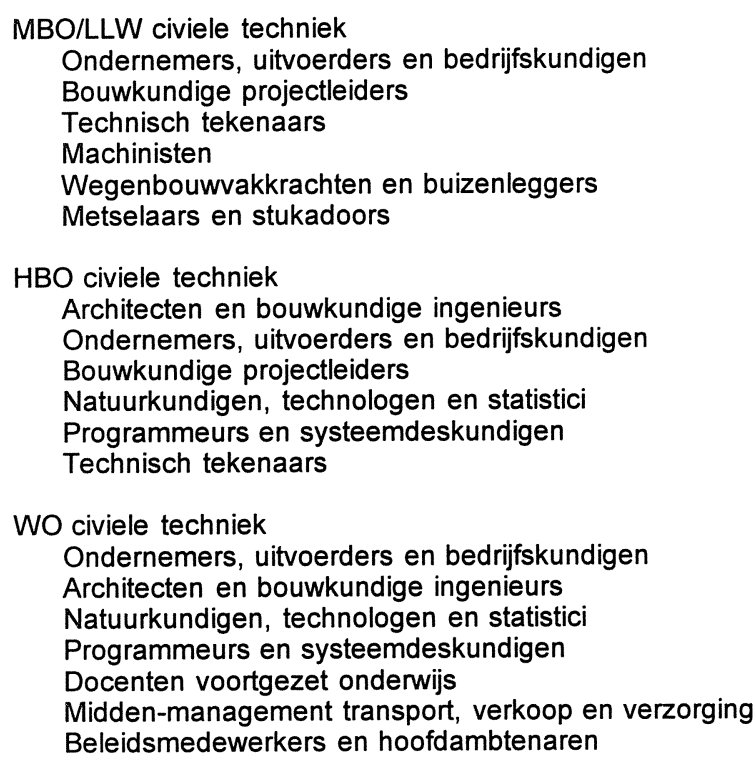


Tabel 4.1 geeft de belangrijkste beroepsklassen waarin civiel-technisch opgeleiden werkzaam zijn. Het betreft de beroepsklassen die minstens $2 \%$ van de werkgelegenheid uitmaken. In deze lijst komen hoofdzakelijk toch weer de op de GWWsector gerichte technische beroepen voor. Dit wordt veroorzaakt doordat de spreiding over de andere beroepen veel groter is, zodat in vrijwel geen van deze beroepen een substantieel deel van de werkgelegenheid wordt bereikt. De beroepen waarin civiel-technisch opgeleiden werkzaam zijn, variëren echter van onderwijzer tot verkoper en ook bijvoorbeeld beroepsmilitair.

De belangrijkste beroepsklassen voor MBO/LLW civiele techniek zijn 'ondernemers, uitvoerders en bedrijfskundigen' en 'bouwkundige projectleiders'. Daarna volgen de 'technisch tekenaars' maar ook meer uitvoerend werk zoals 'metselaars en stukadoors'. Ook op HBO-niveau vormen de beroepsklassen 'ondernemers, uitvoerders en bedrijfskundigen' en 'bouwkundige projectleiders' een belangrijk deel van de werkgelegenheid, maar de lijst wordt aangevoerd door 'architecten en bouwkundige ingenieurs'. Verder zijn veel HBO'ers civiele techniek werkzaam als technisch tekenaar of als statisticus, programmeur of systeemdeskundige. Voor WO civiele techniek blijkt een vergelijkbaar beroepsdomein te bestaan. Daarbij zijn zij echter ook vaak werkzaam als beleidsambtenaar, docent in het voortgezet onderwijs of in het midden-management transport, verkoop en verzorging. De gepresenteerde beroepsklassen die worden uitgeoefend door personen met een opleiding MBO/LLW civiele techniek zijn te zamen goed voor $33 \%$ van de werkgelegenheid, de overige $67 \%$ is verdeeld over vele beroepsklassen. Voor HBO en WO civiele techniek nemen de gepresenteerde beroepsklassen ongeveer $40 \%$ van de werkgelegenheid in, de overige $60 \%$ is vooral bij het $\mathrm{HBO}$ verdeeld over vele beroepsklassen.

Om de spreiding van een opleidingstype over de beroepsgroepen aan te duiden kan gebruik gemaakt worden van de Gini-Hirschman-spreidingsindicator. Deze index is 0 als de werkgelegenheid van een opleidingstype zich concentreert in één beroep, en is 1 als de werkgelegenheid gelijk gespreid is over alle beroepsgroe$p^{2}{ }^{2}$. De indicator geeft aan hoeveel uitwijkmogelijkheden een opleidingstype op de arbeidsmarkt heeft. Het belang van deze indicator voor het wervingsbeleid is dat bij hoge uitwijkmogelijkheden rekening gehouden moet worden met de aantrekkingskracht van werkgevers in andere beroepssegmenten. In tabel 4.2 is deze beroepenspreiding aangegeven. Hierbij zijn beroepsgroepen beneden het opleidingsniveau buiten beschouwing gebleven. Net als veel andere technische

2. De Gini-Hirschman-spreidingsindex verloopt overigens niet lineair. In totaal worden er meer dan 300 beroepsgroepen onderscheiden, maar als de werkgelegenheid gelijk verdeeld is over tien beroepsgroepen, dan is de index reeds ongeveer 0,90. 
opleidingen heeft ook civiele techniek een gemiddelde beroepenspreiding. Uit het reeds eerder aangehaalde onderzoek van Borghans, De Grip en Smits (1995) blijkt dat technisch opgeleiden weliswaar meestal slechts in zeer specifieke beroepen binnen de techniek werkzaam zijn, maar dat zij buiten de techniek uitwaaieren over een scala aan beroepsgroepen.

Tabel 4.2

Uitwijkmogelijkheden naar verschillende beroepsgroepen op een aansluitend of hoger functieniveau per opleidingsrichting, gemiddelde 1993-1994

\begin{tabular}{lll}
\hline Opleidingsrichting & $\begin{array}{l}\text { Gini-Hirschman } \\
\text { spreidingsindex }\end{array}$ & typering \\
\hline MBO/LLW civiele techniek & 0,91 & gemiddeld \\
MBO/LLW bouwkunde & 0,89 & $\begin{array}{l}\text { gemiddeld } \\
\text { laag }\end{array}$ \\
MBO landmeetkunde & 0,79 & gemiddeld \\
HBO civiele techniek & 0,89 & gemiddeld \\
HBO bouwkunde & 0,86 & gemiddeld \\
HBO landmeetkunde & 0,83 & gemiddeld \\
WO civiele techniek & 0,89 & laag \\
WO bouwkunde & 0,68 & erg laag \\
WO geodesie & 0,50 &
\end{tabular}

Bron: ROA

Vergeleken met bouwkunde en landmeetkunde blijkt civiele techniek op alle onderscheiden opleidingsniveaus meer uitwijkmogelijkheden te kennen. Op MBO- en WO-niveau kent landmeetkunde beduidend minder beroepenspreiding, terwijl ook WO bouwkunde aanzienlijk minder uitwijkmogelijkheden kent. Op HBO-niveau zijn de verschillen tussen de drie genoemde opleidingen het geringst.

Tabel 4.3 geeft per opleidingsniveau aan in welke bedrijssectoren civiel technici werkzaam zijn. Voor MBO/LLW civiele techniek is de bouw de belangrijkste bedrijfssector. $44 \%$ procent van deze groep is hier werkzaam. Daarbinnen is $81 \%$ werkzaam bij de GWW-bouwbedrijven. Dit betekent dat hoewel de GWW-bedrijven de belangrijkste bedrijfsklasse voor MBO'ers civiele techniek is, toch slecht $36 \%$ ( $81 \%$ van $44 \%$ ) hier werkzaam is. Naast de GWW-bedrijven, zijn de overheid en de overige commerciële dienstverlening - met name de ingenieursbureaus en dergelijke - een belangrijke afnemer van civiel-technisch opgeleiden op MBO/LLW-niveau. Voor HBO'ers civiele techniek blijken de overheid en de ingenieursbureaus belangrijkere werkgevers te zijn dan de GWW-bedrijven. $39 \%$ van de HBO'ers werkt bij de overheid; $20 \%$ bij ingenieursbureaus en slechts $18 \%$ in de bouw. $13 \%$ van de civiel-technische HBO'ers werkt bij GWW-bedrijven in de bouw. Ook WO civiele techniek kent dezelfde top-drie van bedrijfsklassen, maar 
ook hier wisselt wederom de volgorde. Voor WO'ers zijn de ingenieursbureaus de belangrijkste werkgevers, gevolgd door eerst de overheid en dan de bouw.

Tabel 4.3

Belangrijkste bedrijfssectoren/klassen per opleidingsrichting, gemiddelde 1993-1994

Opleidingsrichting

MBO/LLW civiele techniek

Bouw

44

Grond-, water- en wegenbouwkundige bedrijven

Burgelijke en utiliteitsbedrijven

Exploitatie van en handel in onroerend goed e.d.

Overheid

Algemene overheidsadministraties

24

Overige commerciële dienstverlening

Ingenieurs-, architecten- e.a. technische ontwerp- en adviesbureaus

Transport, opslag en communicatie

Landbouw en visserij

Energie

Overige industrie

Metaal en elektrotechniek

Handel

HBO civiele techniek

Overheid

Algemene overheidsadministraties

39

Overige commerciële dienstverlening

Ingenieurs-, architecten- e. technische ontwerp- en adviesbureaus Bouw

18

Grond-, water- en wegenbouwkundige bedrijven

Kwartaire diensten

Transport, opslag en communicatie

Overige industrie

Handel

Landbouw en visserij

WO civiele techniek

Overige commerciële dienstverlening

Ingenieurs-, architecten- e.a. technische ontwerp- en adviesbureaus

Overheid

Algemene overheidsadministraties

Bouw

Kwartaire diensten

Metaal en elektrotechniek

Landbouw en visserij

Transport, opslag en communicatie

Energie

Handel

Bron: CBS/ROA 
Tabel 4.4

Belangrijkste bedrijfssectoren voor werkzame schoolverlaters per opleidingsrichting, 1994

\begin{tabular}{lc}
\hline Opleidingsrichting & $\%$ \\
\hline MBO civiele techniek & 74 \\
Bouw & 15 \\
Overige commerciële dienstverlening & 6 \\
Transport, opslag en communicatie & 5 \\
Overheid & \\
HBO civiele techniek & 40 \\
Overige commerciële dienstverlening & 28 \\
Overheid & 17 \\
Bouw & 6 \\
Metaal en elektrotechniek & \\
w.v. verkeerskunde & 32 \\
Overheid & 30 \\
Overige commerciële dienstverlening & 16 \\
Metaal en elektrotechniek & 8 \\
Handel & \\
w.v. weg- en waterbouwkunde & 25 \\
Overige commerciële dienstverlening & 24 \\
Overheid & 25 \\
Bouw & \\
\hline Bron. & \\
\hline
\end{tabular}

Bron: RUBS/HBO-Monitor/ROA

Tabel 4.4 geeft een overzicht van de belangrijkste bedrijfssectoren voor werkzame schoolverlaters civiele techniek. Deze gegevens over de bestemming van schoolverlaters van civiel-technische opleidingen komen in grote lijnen overeen met de lijst van belangrijkste werkgevers voor de gehele werkzame beroepsbevolking met de desbetreffende opleidingsachtergrond. Voor de schoolverlaters van het MBO is het belang van de bouw met $74 \%$ echter aanzienlijk groter. Het aantal arbeidsplaatsen bij de overheid bedraagt voor schoolverlaters civiele techniek echter slechts $5 \%$. Dit verschil weerspiegelt de veranderde verhoudingen, waar de overheid steeds minder voor nieuwkomers op de arbeidsmarkt werk kan bieden. Ook op het HBO-niveau neemt het belang van de overheid als werkgever af, al vindt nog steeds $28 \%$ van de schoolverlaters op dit niveau werk bij de overheid. De overige commerciële dienstverlening - waartoe de ingenieursbureaus behoren - nemen echter maar liefst $40 \%$ van de afgestudeerden af. Binnen HBO civiele techniek is de werkgelegenheid voor weg- en waterbouwkunde nagenoeg hetzelfde verdeeld als voor civiele techniek in het totaal. De verkeerskundigen daarentegen werken voor éénderde bij de overheid en de overige commerciële dienstverlening, terwijl er bijna niemand in de bouw werkt. 

Dezelfde informatie is niet beschikbaar voor het WO-niveau. Tabel 4.5 geeft echter aan bij welke bedrijfssectoren TU-ingenieurs werkzaam zijn volgens de KIvlsalaris-enquête. Doordat bij dit onderzoek een afwijkende indeling wordt gehanteerd kan voor de TU-ingenieurs ook aangegeven worden hoeveel personen er werkzaam zijn bij de publieke werken en waterstaat. Zoals verwacht kon worden, zijn deze publieke werken en waterstaat met $16 \%$, de ingenieursbureaus met $34 \%$, de bouw met $20 \%$ en de overige overheid met $14 \%$ de belangrijkste groepen werkgevers. Dit patroon komt het meest overeen met de werkgelegenheidsspreiding van WO bouwkunde. Daarentegen hebben ook de opleidingsrichtingen werktuigbouwkunde en elektrotechniek/informatica op WO-niveau onderling ongeveer dezelfde werkgelegenheidsspreiding die echter erg afwijkt van WO civiele techniek en bouwkunde.

Tabel 4.6

Uitwijkmogelijkheden werkzame schoolverlaters naar verschillende beroepsgroepen per opleidingsrichting, 1994

\begin{tabular}{|c|c|c|}
\hline Opleidingsrichting & $\begin{array}{l}\text { Gini-Hirschman } \\
\text { spreidingsindex }\end{array}$ & typering \\
\hline $\begin{array}{l}\text { MBO civiele techniek } \\
\text { MBO bouwkunde } \\
\text { MBO landmeetkunde }\end{array}$ & $\begin{array}{l}0,77 \\
0,83 \\
0,52\end{array}$ & $\begin{array}{l}\text { laag } \\
\text { gemiddeld } \\
\text { erg laag }\end{array}$ \\
\hline $\begin{array}{l}\text { HBO civiele techniek } \\
\text { w.v. verkeerskunde } \\
\text { weg- en waterbouwkunde } \\
\text { HBO bouwkunde }\end{array}$ & $\begin{array}{l}0,87 \\
0,59 \\
0,84 \\
0,73\end{array}$ & $\begin{array}{l}\text { gemiddeld } \\
\text { erg laag } \\
\text { gemiddeld } \\
\text { laag }\end{array}$ \\
\hline
\end{tabular}

Bron: RUBS/HBO-Monitor/ROA

Tabel 4.7

Uitwijkmogelijkheden werkzame schoolverlaters naar verschillende bedrijfsklassen per opleidingsrichting, 1994

\begin{tabular}{lll}
\hline Opleidingsrichting & $\begin{array}{l}\text { Gini-Hirschman } \\
\text { spreidingsindex }\end{array}$ & typering \\
\hline MBO civiele techniek & 0,48 & erg laag \\
MBO bouwkunde & 0,68 & laag \\
MBO landmeetkunde & $\cdot$ & - \\
HBO civiele techniek & 0,78 & laag \\
W.V. verkeerskunde & 0,85 & gemiddeld \\
weg- en waterbouwkunde & 0,71 & laag \\
HBO bouwkunde & 0,67 & laag \\
\cline { 1 - 2 } & &
\end{tabular}

Bron: RUBS/HBO-Monitor/ROA 
Ter afsluiting van dit hoofdstuk geven tabel 4.6 en 4.7 een overzicht van respectievelijk de beroepenspreiding en de bedrijfsklassespreiding van werkzame schoolverlaters. In tegenstelling tot de cijfers voor de gehele werkzame beroepsbevolking blijken zowel de uitwijkmogelijkheden naar verschillende beroepsgroepen en naar verschillende bedrijfsklassen voor schoolverlaters op MBO- en HBOniveau aanmerkelijk lager te zijn. Dit spoort met de bevindingen van Borghans, De Grip en Smits (1995) dat schoolverlaters in hun eerste baan toch nog sterk afhankelijk zijn van vakspecifiek werk. Pas nadat zij enige werkervaring hebben opgedaan lijkt het voor hen mogelijk te zijn om uit te wijken naar minder specifiek op civiele techniek gerichte beroepen en bedrijfssectoren. Met name voor de werving van nieuwkomers op de arbeidsmarkt lijken de bedrijven in de GWWsector in de ruime zin des woords (inclusief de overheid en de ingenieursbureaus) dus een voordeel te hebben. Bij meer ervaren krachten kan de concurrentie met andere beroepsgroepen en bedrijfsklassen groter worden.

Geconcludeerd kan worden dat de arbeidsmarktspreiding van civiel-technisch opgeleiden over beroepsgroepen en bedrijfsklassen in het algemeen slechts laag is voor werkzame schoolverlaters en gemiddeld voor de gehele werkzame beroepsbevolking, maar wel degelijk aanwezig is. Uitgaande van technische bedrijven of beroepen betekent dit dat zij op de arbeidsmarkt ten aanzien van met name ervaren civiel technici, zoals reeds eerder is opgemerkt, moeten concurreren met andere niet-technische beroepsgroepen en bedrijsklassen. Het positieve van deze arbeidsmarktconcurrentie is dat er een potentieel is aan civiel technici die 'terug kunnen worden gewonnen', het negatieve is echter dat men eveneens civieltechnisch opgeleiden 'kwijt kan raken'. 


\section{De salariëring van civiel-technisch opgeleiden}

Discrepanties op de arbeidsmarkt kunnen aanleiding geven tot beloningsverschillen tussen opleidingsrichtingen op eenzelfde niveau. Omgekeerd kunnen beloningsverschillen voor mensen met eenzelfde opleidingsachtergrond tussen verschillende sectoren leiden tot recruteringsproblemen in de qua beloning achterblijvende bedrijfssectoren. In dit hoofdstuk wordt daarom kort ingegaan op de beloning van de civiel-technisch opgeleiden.

Tabel 5.1

Gemiddeld bruto maandloon van werkzame schoolverlaters" en TU Delft civiel technici“ per opleidingsrichting, 1994

\begin{tabular}{|c|c|c|}
\hline Opleidingsrichting & $\begin{array}{l}\text { gemiddeld bruto } \\
\text { maandloon, } \\
\text { guldens }\end{array}$ & typering \\
\hline $\begin{array}{l}\text { MBO civiele techniek } \\
\text { MBO bouwkunde } \\
\text { MBO landmeetkunde }\end{array}$ & $\begin{array}{r}2.498 \\
2.380 \\
.\end{array}$ & $\begin{array}{l}\text { hoog voor havo/vwo/mbo } \\
\text { gemiddeld havo/vwo/mbo } \\
\text { - }\end{array}$ \\
\hline $\begin{array}{l}\text { HBO civiele techniek } \\
\text { W.V. verkeerskunde } \\
\text { weg- en waterbouwkunde } \\
\text { HBO bouwkunde }\end{array}$ & $\begin{array}{l}3.364 \\
3.423 \\
3.346 \\
3.310\end{array}$ & $\begin{array}{l}\text { gemiddeld voor hbo } \\
\text { gemiddeld voor hbo } \\
\text { gemiddeld voor hbo } \\
\text { gemiddeld voor hbo }\end{array}$ \\
\hline $\begin{array}{l}\text { TU Delft civiele techniek } \\
\text { incl. toeslagen } \\
\text { excl. toeslagen }\end{array}$ & $\begin{array}{l}4.572 \\
4.464\end{array}$ & - \\
\hline
\end{tabular}

Bron: RUBS/HBO-Monitor/ROA, TU Delft

inclusief toeslagen ploegendienst of fooien

* najaar 1992

Tabel 5.1 geeft allereerst een overzicht van het gemiddeld bruto maandloon voor de drie opleidingsniveaus. Het salaris voor schoolverlaters met HBO civiele techniek als opleidingsachtergrond wijkt niet af van het gemiddelde voor het HBO. Het gemiddelde bruto maandloon voor civiel-technisch opgeleide HBO'ers is ongeveer $f 3.400$,-. MBO'ers civiele techniek blijken daarentegen wel een relatief hoog salaris te verdienen. Hun gemiddelde bruto maandloon is ongeveer $f 2.500,-$, terwijl dat voor MBO'ers bouwkunde ongeveer $f 2.400,-$ is. De beloning voor schoolverlaters WO civiele techniek kan niet vergeleken worden met andere (technische) opleidingen op WO-niveau, omdat daartoe de informatie ontbreekt. Zij verdienen (inclusief toeslagen) gemiddeld rond de $f$ 4.600,- bruto per maand. Het verschil in bruto maandloon tussen personen die op het moment van enquêteren één jaar (1991) en twee jaar (1990) zijn afgestudeerd is het grootst. Personen die in 1991 zijn afgestudeerd verdienen gemiddeld $f$ 3.893,- bruto per maand (inclusief 
toeslagen). Voor degenen die in 1990, 1989 en 1988 zijn afgestudeerd is dit respectievelijk $f$ 4.461,-, $f$ 4.751,- en $f$ 5.007,-- Uit de Arbeidsmarktscanner Rijksuniversiteit Limburg (1994) ${ }^{3}$ blijkt dat het bruto maandinkomen (exclusief toeslagen) bij een veertigurige werkweek onder betaalde werkende afgestudeerden van de Rijksuniversiteit Limburg gemiddeld $f 4.007,-$ is. De verschillen in maandinkomen tussen de onderscheiden faculteiten (Faculteit der Geneeskunde (FdG), Faculteit der Rechtsgeleerdheid (FdR), Faculteit der Gezondheidswetenschappen ( $F d G W$ ) en de Faculteit der Economische Wetenschappen (FdEW)) zijn groot. Juristen die de avondopleiding hebben gevolgd en basisartsen hebben gemiddeld de hoogste inkomens, respectievelijk $f$ 5.304,- en $f$ 4.956,-. Economen verdienen, na juristen van de dagopleiding ( $f 3.388,-)$, gemiddeld het minst: $f 3.868,-$.

Tabel 5.2 geeft informatie over de beloning van TU-ingenieurs op basis van de Klvl-salaris-enquête. Het blijkt dat civiel-technisch ingenieurs het hoogste salaris verkrijgen in de bouwsector. In de meeste sectoren wordt echter niet door civielingenieurs het hoogste gemiddelde salaris verdiend. Meestal is de beloning voor werktuigbouwkundigen aanzienlijk hoger. Ook elektrotechnici en informatici verdienen in een aantal sectoren een erg hoog loon. Bij de ingenieursbureaus, bij de overige overheid en voor zover bekend ook bij publieke werken en waterstaat verdienen civiel-ingenieurs echter gemiddeld meer dan de andere in de tabel onderscheiden opleidingsrichtingen.

In tabel 5.3 worden de beloningen voor TU-ingenieurs uitgesplitst naar leeftijd. Ook hier blijkt wederom het salaris van werktuigbouwkundigen doorgaans het hoogst te zijn. De verschillen met civiele techniek zijn echter niet erg groot en voor de leeftijdsgroep 50-64 jaar blijken civiel-ingenieurs zelfs gemiddeld meer te verdienen. Vanaf $\mathbf{4 0}$ jaar blijkt alleen het salaris van bouwkundigen sterk achter te blijven bij het met de leeftijd oplopende salaris van TU-ingenieurs.

3. Dit betreft de resultaten van de enquête onder de in 1992 afgestudeerden van de Rijksuniversiteit Limburg, die één jaar na afstuderen geënquêteerd zijn. 


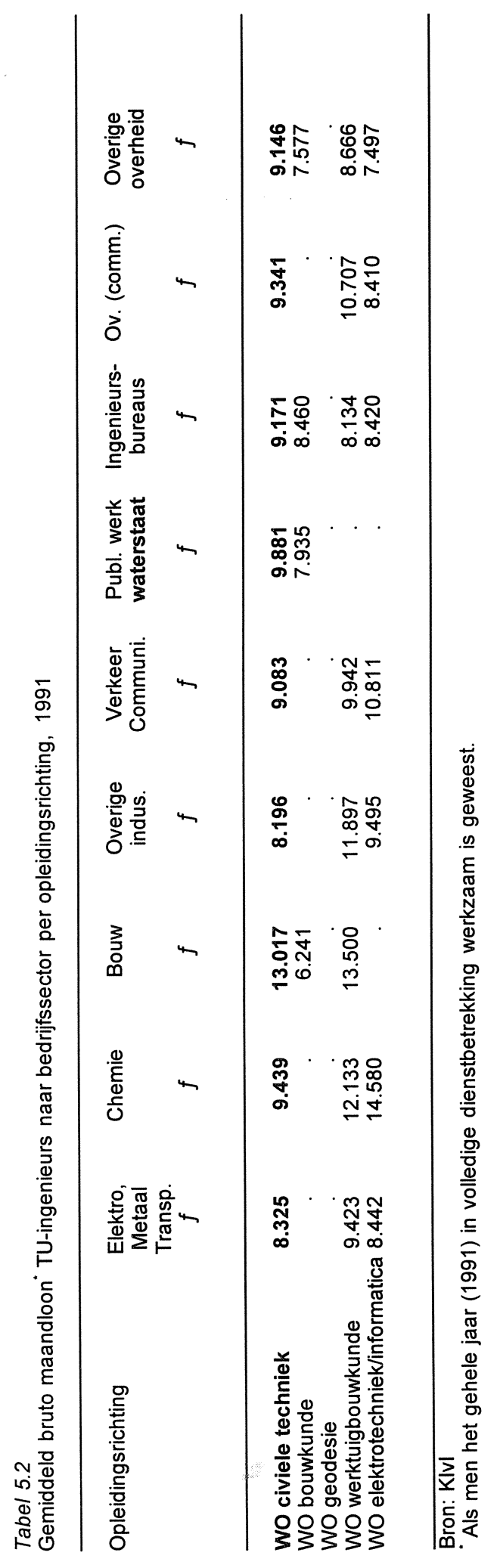


Tabel 5.3

Gemiddeld bruto maandloon ${ }^{*}$ TU-ingenieurs naar leeftijd per opleidingsrichting, 1991

\begin{tabular}{lrrrr}
\hline Opleidingsrichting & $\begin{array}{r}15-29 \text { jaar } \\
\text { guldens }\end{array}$ & go-39 jaar & $40-49$ jaar & $50-64$ jaar \\
guldens & guldens & & \\
& guldens
\end{tabular}

\section{Bron: KIvI}

Als men het gehele jaar (1991) in volledige dienstbetrekking werkzaam is geweest.

\section{Figuur 5.1}

Verdeling gemiddeld bruto maandloon van civiel-technisch ingenieurs totaal en bij publieke werken en waterstaat, 1991

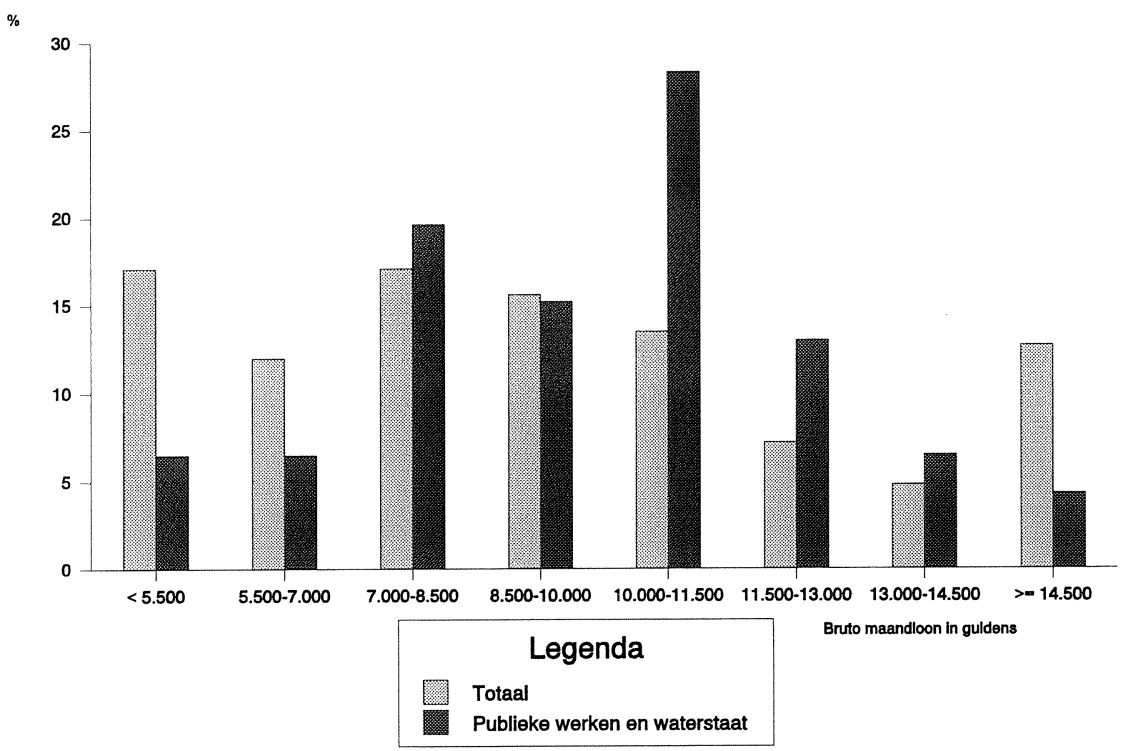

Bron: KIvI

Figuur 5.1 geeft een overzicht van de verdeling van het gemiddeld bruto maandIoon van civiel-technisch ingenieurs in het algemeen en van civiel-technisch ingenieurs die werkzaam zijn bij publieke werken en waterstaat. De verschillen in de verdeling van het gemiddeld bruto maandloon tussen de twee groepen zijn groot. Het overgrote deel van de academisch opgeleide civiel technici dat werk- 
zaam is bij publieke werken en waterstaat verdient gemiddeld een bruto maandloon tussen de 7.000 en 11.500 gulden. Vergeleken met de civiel-technisch ingenieurs in het algemeen verdienen (erg) veel civiel-technisch ingenieurs bij publieke werken en waterstaat een bruto maandloon van $f$ 10.000,- tot $f 11.500,-$, van $f 7.000$,- tot $f 8.500$,- en van $f 11.500,-$ tot $f 13.000,-$. Daarentegen zijn er relatief weinig civiel-technisch ingenieurs bij publieke werken en waterstaat die een bruto maandloon tussen de $f 4.000$,- en $f 7.000$,- of $f 14.500$,- en meer verdienen. Hier kan echter een verschil in de leeftijdsopbouw een rol spelen. 


\section{Uitbreidingsvraag 1995-2000}

De in de vorige hoofdstukken besproken gegevens geven een beeld van de actuele situatie van de arbeidsmarktpositie van civiel-technisch opgeleiden. Met name voor civiele techniek op HBO- en WO-niveau lijkt de arbeidsmarktpositie gunstig (lage werkloosheid, werkzaam in de eigen vakrichting en op het eigen niveau, veelal vast dienstverband en voltijdbaan), wat kan wijzen op een relatieve schaarste van deze groepen. De keerzijde van deze medaille is dat er wellicht sprake zal zijn van wervingsproblemen bij deze categorieën personeel. Om tijdig in te kunnen spelen op de ontwikkelingen op de arbeidsmarkt is het echter van belang niet alleen naar de actuele situatie, maar ook naar de toekomstige ontwikkelingen op de arbeidsmarkt te kijken. De situatie op de arbeidsmarkt voor een bepaald opleidingstype kan immers in de loop der jaren omslaan als gevolg van veranderingen aan de vraagkant, door wijzigingen in de produktie in een bepaalde bedrijfssector of vanwege veranderingen in de arbeidsproduktiviteit. Daarnaast kan er een behoefte aan nieuw personeel ontstaan als gevolg van de uittrede (pensionering, VUT, maar ook WAO-intrede) van zittend personeel. Verder wordt de vraag-aanbod-verhouding op de arbeidsmarkt in belangrijke mate bepaald door de instroom naar de arbeidsmarkt vanuit het onderwijs. De populariteit van bepaalde studierichtingen onder studenten kan immers vrij drastisch wijzigen.

In de volgende drie hoofdstukken wordt daarom ingegaan op achtereenvolgens de verwachte uitbreidingsvraag, de verwachte vervangingsvraag en de verwachte instroom van schoolverlaters voor de periode 1995-2000. In hoofdstuk 9 worden vraag en aanbod voor deze periode tegenover elkaar gezet, op grond waarvan geconcludeerd kan worden of er moeilijkheden in de personeelsvoorziening verwacht kunnen worden, of dat er juist sprake zal zijn van een overvloed aan aanbod van civiel-technisch opgeleiden. Vervolgens zullen in hoofdstuk 10 vraag en aanbod voor de periode 2000-2010 worden geanalyseerd. In hoofdstuk 11 wordt daarna nog ingegaan op de vraag welke marges er zijn voor aanpassings-mechanismen gericht op het voorkomen van eventuele discrepanties op de arbeidsmarkt voor civiel-technisch opgeleiden.

In dit hoofdstuk wordt allereerst dus ingegaan op de verwachte uitbreidingsvraag voor de periode 1995-2000. Deze prognoses zijn gebaseerd op het Informatiesysteem Onderwijs-Arbeidsmarkt. In het kader van dit informatiesysteem zijn onlangs prognoses voor De arbeidsmarkt naar opleiding en beroep tot 2000 tot stand gekomen (zie ROA, 1995a,b,c). Het vertrekpunt van deze arbeidsmarktprognoses zijn de voorspellingen van het Centraal Planbureau (CPB) met betrekking tot de sectorale economische ontwikkelingen op de middellange termijn. Het ATHENAmodel van het CPB levert prognoses voor de vraag naar arbeid in manjaren. Voor 
een vraag-aanbod-confrontatie is het echter zinvoller een vergelijking te maken in personen. Daartoe worden de voorspelde volume-ontwikkelingen omgerekend naar de verwachte vraag in personen. Dit gebeurt met behulp van de zogenaamde p/aratio. Deze ratio, die ook door het CPB wordt geprognosticeerd, geeft aan hoeveel mensen er werkzaam zullen zijn per full-time arbeidsplaats. Voor bijvoorbeeld de bedrijfssector bouw - waar traditioneel niet veel part-time wordt gewerkt - is deze ratio thans 1,031 , en wordt een toename verwacht tot 1,042 in het jaar 2000. Voor de overheid groeit de ratio in deze periode van 1,128 naar 1,148 . Dit levert uiteindelijk een beeld op van de vraag naar arbeid per sector tot het jaar 2000. Voor de voor deze studie meest relevante bedrijfssectoren wordt een jaarlijkse procentuele groei verwacht van 0,6 voor de bouw, 1,9 voor de overige commerciële dienstverlening en $-0,9$ voor de overheid.

Binnen de onderscheiden bedrijfssectoren kunnen er echter ook verschuivingen optreden in de beroepenstructuur van de werkgelegenheid. Daarvoor heeft het ROA een beroepenmodel ontwikkeld waarin de vraag naar arbeid per beroepsklasse wordt voorspeld. Deze ontwikkeling per beroepsklasse hangt naast de sectorale ontwikkeling af van enkele verklarende variabelen zoals de produktiviteitsontwikkeling en bezettingsgraad in de desbetreffende bedrijfssector. Daarnaast worden bestaande trends in de beroepenstructuur van bedrijfssectoren geëxtrapoleerd. De verwachte groei (of krimp) per beroep kan aanzienlijk verschillen van de sectorgroei. Zo wordt voor de beroepsklasse 'ondernemers, uitvoerders en bedrijfskundigen' een jaarlijkse groei van $2,9 \%$ verwacht. Voor 'architecten en bouwkundige ingenieurs' zal de jaarlijkse groei naar verwachting $0,9 \%$ bedragen. Bij de 'beleidsmedewerkers en hoofdambtenaren' wordt een jaarlijkse krimp van $4,0 \%$ verwacht.

De vraag per beroepsklasse geeft aan in welke functies de werkenden de komende tijd zullen worden ingezet. De invulling van deze functies kan geschieden door het inzetten van mensen met een specifieke of juist sterk uiteenlopende opleidingsachtergrond. Bij een groot deel wordt dit bepaald door de personen die reeds werkzaam zijn in dit beroep. Bij de vraag naar nieuwkomers is er echter doorgaans sprake van een keuzemogelijkheid voor de werkgever. In het opleidingenmodel wordt vervolgens voorspeld voor welke opleidingsachtergrond er in bepaalde beroepen vraag zal ontstaan. Bij een aantal functies blijken werkgevers zeer specifiek bij bepaalde opleidingen te werven. Veelal ziet men hierbij wel een verschuiving in de loop der tijd van lagere naar hogere opleidingsniveaus. Andere functies blijken toegankelijk te zijn voor mensen met uiteenlopende opleidingsachtergronden. Ook hier is in het algemeen sprake van een upgradingstendens, terwijl daarnaast tevens sprake is van een neiging tot concentratie. Dat wil zeggen dat werkgevers meer en meer vraag uitoefenen naar personen met de meest aansluitende opleidingsrichting, terwijl de vraag naar minder aansluitende richtingen neigt af te nemen. 
Voor de meeste specifieke functies in de GWW-sector wordt grotendeels geworven onder civiel-technisch opgeleiden. Voor de arbeidsmarkt van de opleidingen civiele techniek zijn echter ook de ontwikkelingen bij andere functies van belang. Zoals in hoofdstuk 4 werd aangegeven is immers een groot deel van de civiel-technisch opgeleiden werkzaam buiten de GWW-sector. Met name voor beroepen die meer algemeen technische vaardigheden vereisen, zoals programmeurs en systeemanalysten zal ook bij civiele techniek gerecruteerd worden.

Tabel 6.1

Uitbreidingsvraag per opleidingsrichting, 1995-2000

\begin{tabular}{|c|c|c|c|}
\hline Opleidingsrichting & $\%$ '95-'00 & jaarlijks \% & typering \\
\hline \multicolumn{4}{|l|}{ MBO/LLW } \\
\hline $\begin{array}{l}\text { bouwkunde/civiele techniek } \\
\text { civiele techniek } \\
\text { w.v. beroepseffect }\end{array}$ & $\begin{array}{l}3,1 \\
7,9 \\
6,7\end{array}$ & $\begin{array}{l}0,6 \\
1,5 \\
1,3\end{array}$ & $\begin{array}{l}\text { laag } \\
\text { gemiddeld } \\
-\end{array}$ \\
\hline \multicolumn{4}{|l|}{ HВO } \\
\hline $\begin{array}{l}\text { bouwkunde/civiele techniek } \\
\text { civiele techniek } \\
\text { w.v. beroepseffect }\end{array}$ & $\begin{array}{l}14,5 \\
15,7 \\
14,1\end{array}$ & $\begin{array}{l}2,7 \\
3,0 \\
2,7\end{array}$ & $\begin{array}{l}\text { hoog } \\
\text { hoog } \\
-\end{array}$ \\
\hline \multicolumn{4}{|l|}{ wo } \\
\hline $\begin{array}{l}\text { bouwkunde/civiele techniek } \\
\text { civiele techniek } \\
\text { w.v. beroepseffect }\end{array}$ & $\begin{array}{l}19,9 \\
24,6 \\
23,3\end{array}$ & $\begin{array}{l}3,7 \\
4,5 \\
4,3\end{array}$ & $\begin{array}{l}\text { hoog } \\
\text { erg hoog } \\
\text { - }\end{array}$ \\
\hline
\end{tabular}

Bron: ROA

In tabel 6.1 wordt weergegeven hoeveel de vraag zal groeien voor de opleidingstypen bouwkunde inclusief civiele techniek en civiele techniek afzonderlijk. Voor het gecombineerde opleidingstype bouwkunde/civiele techniek wordt voor het MBO/LLW een uitbreidingsvraag van $3,1 \%$, voor het $H B O$ van $14,5 \%$ en voor het WO van $19,9 \%$ verwacht. Omdat voor deze studie echter alleen de groep civiel technici van belang is, zijn de prognoses voor deze groep verder verbijzonderd. Hierbij is rekening gehouden met twee aspecten.

Ten eerste zijn civiel-technisch opgeleiden niet in gelijke mate vertegenwoordigd in de beroepen waarin bouwkundigen vertegenwoordigd zijn. Voor het MBO/LLW en het WO betekent dit een hogere uitbreidingsvraag van respectievelijk $6,7 \%$ en $23,3 \%$. De vraag op HBO-niveau voor civiele techniek is op grond van dit beroepseffect iets lager dan de uitbreidingsvraag voor de gehele groep bouwkunde/civiele techniek, namelijk 14,1 in plaats van $14,5 \%$. 
Naast het verschil in beroepenstructuur, zal echter ook de groei binnen een beroepsklasse niet gelijk zijn voor bouwkundigen en civiel-technisch opgeleiden. De prognoses van het CPB maken echter geen onderscheid tussen de GWW-sector en de rest van de bouw. Daarom zijn de uitbreidingsvraagprognoses voor civieltechnisch opgeleiden verder verbijzonderd met behulp van de specifiek op de bouw gerichte voorspellingen van het Economisch Instituut voor de Bouwnijverheid (EIB). Aartman e.a. (1995) voorspellen dat de produktiegroei tussen 1995 en 2000 in de GWW-sector $10 \%$ zal bedragen, terwijl de produktiegroei voor de rest van de bouwsector naar verwachting slechts $6 \%$ zal bedragen. Dit verschil in groeisnelheid is verdisconteerd in de prognoses voor de meest specifieke beroepssegmenten, namelijk 'middelbare technische, ambachts- en industrieberoepen' en 'architecten, geodeten e.a. hogere bouwkundigen'. Bij de overheidsfuncties is voorzichtigheidshalve geen verschil gemaakt tussen de groei (per saldo krimp) van bouwkundigen en civiel-technisch opgeleiden. Inclusief het groeieffect bedraagt de prognose voor de uitbreidingsvraag voor de komende vijf jaren $7,9 \%$ voor het MBO/LLW, 15,7\% voor het $\mathrm{HBO}$ en $24,6 \%$ voor het WO. 


\section{Vervangingsvraag 1995-2000}

Naast de uitbreidingsvraag is ook de vervangingsvraag een cruciale grootheid voor het in kaart brengen van de toekomstige recruteringsbehoefte. Voor de gehele arbeidsmarkt zal de komende vijf jaar naar verwachting $80 \%$ van alle baanopeningen voortkomen uit een vervangingsbehoefte, terwijl slechts $20 \%$ van de baanopeningen voorkomt uit werkgelegenheidsgroei (zie ROA, 1995a).

De vervangingsvraag wordt voorspeld door een model dat uit de jaarlijkse veranderingen van de omvang van een cohort de uitstroomparameters per leeftijdscategorie bepaald. De uitstroom per leeftijdsgroep geeft aan hoeveel procent van een leeftijdsgroep de arbeidsmarkt verlaat vanwege pensioen, VUT of andere redenen, zoals arbeidsongeschiktheid of de verzorging van kinderen. De analyse wordt apart uitgevoerd voor mannen en vrouwen. Door deze uitstroomparameters te combineren met de actuele leeftijdsopbouw van de beroepsbevolking met de betreffende opleidingsachtergrond, wordt een prognose van de toekomstige uitstroom gemaakt. Omdat de vraag naar civiel-technisch opgeleiden de komende vijf jaar zal groeien, kan verwacht worden dat per saldo deze uitstroom volledig vervangen zal worden. Voor de totale groep zal de vervangingsvraag daarom gelijk zijn aan de uitstroom. Voor specifieke organisaties kan het uiteraard zo zijn dat zij de uitstroom van personeel aangrijpen om een verkleining van het personeelsbestand te realiseren. In dat geval zal de vervangingsvraag kleiner zijn dan de uitstroom.

Tabel 7.1

Vervangingsvraag per opleidingsrichting, $1995-2000$

\begin{tabular}{|c|c|c|c|c|}
\hline Opleidingsrichting & aantal & \% '95-'00 & jaarlijks \% & typering \\
\hline \multicolumn{5}{|l|}{ MBO/LLW } \\
\hline $\begin{array}{l}\text { civiele techniek } \\
\text { bouwkunde } \\
\text { landmeetkunde }\end{array}$ & $\begin{array}{r}1.850 \\
26.800 \\
750\end{array}$ & $\begin{array}{l}11,2 \\
16,5 \\
17,7\end{array}$ & $\begin{array}{l}2,1 \\
3,0 \\
3,3\end{array}$ & $\begin{array}{l}\text { laag } \\
\text { hoog } \\
\text { hoog }\end{array}$ \\
\hline \multicolumn{5}{|l|}{ нво } \\
\hline $\begin{array}{l}\text { civiele techniek } \\
\text { bouwkunde } \\
\text { landmeetkunde }\end{array}$ & $\begin{array}{r}2.400 \\
2.750 \\
550\end{array}$ & $\begin{array}{l}16,2 \\
14,9 \\
37,3\end{array}$ & $\begin{array}{l}3,0 \\
2,8 \\
6,6\end{array}$ & $\begin{array}{l}\text { gemiddeld } \\
\text { gemiddeld } \\
\text { erg hoog }\end{array}$ \\
\hline \multicolumn{5}{|l|}{ wo } \\
\hline $\begin{array}{l}\text { civiele techniek } \\
\text { bouwkunde } \\
\text { geodesie }\end{array}$ & $\begin{array}{r}950 \\
2.500 \\
100\end{array}$ & $\begin{array}{r}18,1 \\
21,9 \\
9,8\end{array}$ & $\begin{array}{l}3,4 \\
4,0 \\
1,9\end{array}$ & $\begin{array}{l}\text { hoog } \\
\text { erg hoog } \\
\text { laag }\end{array}$ \\
\hline
\end{tabular}

Bron: ROA 
In tabel 7.1 wordt de verwachte vervangingsvraag voor civiele techniek en enkele verwante richtingen op de drie opleidingsniveaus gegeven. Op zowel MBO/LLWals WO-niveau is de vervangingsvraag bij civiele techniek lager dan bij bouwkunde. Op het HBO-niveau kent civiele techniek daarentegen een iets hogere vervangingsvraag. Landmeetkunde kent op HBO-niveau een extreem hoge vervangingsvraag en op WO-niveau juist een lage vervangingsvraag. Gezien het feit dat het hier om een erg kleine groep gaat moet bij dit cijfer rekening gehouden worden met een behoorlijke mate van onzekerheid.

In een evenwichtige situatie ligt voor de opleidingen civiele techniek de vervangingsvraag vlak boven de $3 \%$. Dat betekent dat op alle niveaus de werkenden gemiddeld ongeveer 30 jaar op de arbeidsmarkt verblijven. Op MBO/LLW-niveau stroomt men eerder in, maar blijkt men tevens gemiddeld eerder uit te stromen. Dit komt met name vanwege de arbeidsmarktuitstroom naar de WAO. Op HBO-niveau en WO-niveau komt de instroom, vanwege de langere studieduur later op gang, maar blijkt men tevens iets langer op de arbeidsmarkt te verblijven.

Dit betekent dat voor civiele techniek de vervangingsvraag op MBO/LLW-niveau de komende vijf jaar 1\%-punt beneden de vervangingsbehoefte bij een evenwichtige leeftijdsopbouw van de werkenden ligt. Op HBO-niveau zal de uitstroom iets lager zijn dan in een evenwichtige situatie, en op WO-niveau is de komende vijf jaar de uitstroom iets hoger dan normaal. De omvang van de vervangingsvraag bij WO civiele techniek is echter niet dermate hoog dat de komende tijd een tekort aan ervaren krachten verwacht kan worden. 


\section{Het aanbod van schoolverlaters $1995-2000$}

Tegenover de twee vraagcomponenten - uitbreidingsvraag en vervangingsvraag - die in de vorige hoofdstukken werden behandeld, dient het toekomstig aanbod geplaatst te worden, zodat een confrontatie van beide leidt tot een indicatie voor mogelijke problemen in de personeelsvoorziening. Omdat er aan de vraagkant gekeken is naar de baanopeningen, en de werkgelegenheid voor degenen die reeds werkzaam zijn buiten beschouwing is gelaten, dient ook aan de aanbodkant gekeken te worden naar nieuwkomers. De voornaamste groepen die hierbij onderscheiden dienen te worden, zijn de nog boven de markt zwevende groep van kortdurig werklozen en de schoolverlaters. Zoals in hoofdstuk 3 al naar voren kwam is het aantal werklozen, met name op WO- en MBO-niveau zeer beperkt. In dit hoofdstuk wordt dan ook allereerst ingegaan op de instroom van schoolverlaters.

Tabel 8.1

Verwachte instroom van schoolverlaters in aantallen per opleidingsrichting, 1995-2000

\begin{tabular}{|c|c|c|c|c|}
\hline Opleidingsrichting & $\begin{array}{l}\text { regulier } \\
\text { onderwijs }\end{array}$ & $\begin{array}{c}\text { - niet-regulier } \\
\text { onderwijs } \\
\%\end{array}$ & $\begin{array}{c}\text { + niet-regulier } \\
\text { onderwijs } \\
\%\end{array}$ & r totaal \\
\hline \multicolumn{5}{|l|}{ MBO/LLW } \\
\hline $\begin{array}{l}\text { civiele techniek } \\
\text { w.v. leerlingwezen } \\
\text { bouwkunde } \\
\text { w.v. leerlingwezen } \\
\text { landmeetkunde }\end{array}$ & $\begin{array}{r}3.450 \\
13.950 \\
300\end{array}$ & $\begin{array}{r}18,5 \\
12,3 \\
28,7 \\
22,0 \\
6,8\end{array}$ & $\begin{array}{r}54,3 \\
51,9 \\
126,2 \\
124,2 \\
2,0\end{array}$ & $\begin{array}{r}4.700 \\
1.350 \\
27.550 \\
14.250 \\
300\end{array}$ \\
\hline \multicolumn{5}{|l|}{ HBO } \\
\hline $\begin{array}{l}\text { civiele techniek } \\
\text { bouwkunde } \\
\text { landmeetkunde }\end{array}$ & $\begin{array}{r}1.850 \\
2.600 \\
200\end{array}$ & $\begin{array}{r}13,5 \\
8,8 \\
2,6\end{array}$ & $\begin{array}{l}0,8 \\
2,6 \\
0,5\end{array}$ & $\begin{array}{r}1.600 \\
2.450 \\
200\end{array}$ \\
\hline \multicolumn{5}{|l|}{ wo } \\
\hline $\begin{array}{l}\text { civiele techniek } \\
\text { bouwkunde } \\
\text { geodesie }\end{array}$ & $\begin{array}{r}800 \\
1.050 \\
150\end{array}$ & $\begin{array}{l}0,0 \\
0,1 \\
0,0\end{array}$ & $\begin{array}{r}0,3 \\
41,5 \\
0\end{array}$ & $\begin{array}{r}800 \\
1.500 \\
150\end{array}$ \\
\hline
\end{tabular}

Bron: ROA

Tabel 8.1 geeft een overzicht van de gediplomeerde uitstroom vanuit het onderwijs naar de arbeidsmarkt. De eerste kolom van de tabel bevat de uitstroomprognoses zoals die zijn opgesteld in de Referentieraming van het Ministerie van Onderwijs, Cultuur en Wetenschappen (1995). De prognoses van het Ministerie zijn echter niet voldoende verbijzonderd. De uitstroom voor civiele techniek op MBO- en HBO- 
niveau is op basis van een verdeelmodel geschat (zie Borghans en Matheeuwsen, 1995). Op WO-niveau is gebruik gemaakt van de WO Verdeelraming van het Ministerie van Onderwijs, Cultuur en Wetenschappen (1994) om de prognoses uit de Referentieraming te verbijzonderen. De prognoses in de ramingen van het Ministerie zijn gebaseerd op gegevens over de aanwezigheid en doorstroom van leerlingen in de verschillende schooltypen van het onderwijs. Voor het bepalen van de instroom van schoolverlaters naar de arbeidsmarkt wordt uitgegaan van de onen gediplomeerde schoolverlaters uit het reguliere voltijdonderwijs, waarbij de ongediplomeerde schoolverlaters worden toegewezen aan hun hoogst voltooide opleiding. De on- en gediplomeerde uitstroom betreft alleen degenen die werkelijk het reguliere voltijdonderwijs verlaten, en dus niet degenen die verder studeren in een ander regulier voltijd schooltype. De Referentieraming houdt echter geen rekening met het niet-reguliere onderwijs en de verschillende vormen van beroepsgerichte volwasseneneducatie.

Omdat komend jaar de militaire dienstplicht wordt afgeschaft zullen een aantal leerlingen sneller de arbeidsmarkt opstromen. Voor de gehele arbeidsmarkt gaat het om ongeveer 27.700 personen, zodat dit in het algemeen een slechts marginale verhoging van de instroom oplevert. Voor MBO/LLW civiele techniek is het effect van het afschaffen van de militaire dienstplicht echter aanzienlijk. Omdat de opleidingsrichting MBO/LLW civiele techniek vrijwel alleen mannelijke leerlingen kent en deze bovendien voor het overgrote deel in militaire dienst blijken te gaan, zal het komende jaar de instroom naar de arbeidsmarkt drastisch groter zijn. Dit dienstplichteffect is meegerekend in de eerste kolom. Er zijn echter een aantal redenen waarom de uiteindelijke arbeidsmarktinstroom per opleidingsrichting afwijkt van de verwachte arbeidsmarktinstroom vanuit het reguliere voltijdonderwijs. Ten eerste zal een deel van de uitstroom verder studeren in het niet-reguliere onderwijs (waaronder het leerlingwezen, het deeltijd- en tweede fase onderwijs, politie-, defensie- en bewakingsopleidingen en het inservice-onderwijs) of de beroepsgerichte volwasseneneducatie. Dit levert, als de gevolgde niet-reguliere of volwassenenopleiding op een hoger niveau ligt dan de (reguliere) vooropleiding een verlaging van het aantal instromers naar de arbeidsmarkt voor de opleidingsrichting van herkomst en een verhoging van de instroom in de opleidingsrichting van bestemming op. Deze min- en plus-posten worden verrekend in de tweede en derde kolom van de tabel, zodat uiteindelijk de voorspellingen in de laatste kolom resteren. De aantallen van de tweede en derde kolom worden gegeven als percentage van de uitstroom uit het desbetreffende reguliere voltijdonderwijs (eerste kolom).

De tabel laat zien dat op MBO/LLW-niveau het effect van verder studeren vrij substantieel is. Dit betreft veelal het leerlingwezen, dat tot het niet-reguliere onderwijs wordt gerekend. Ook op het HBO-niveau heeft dit effect een negatieve 
invloed op de arbeidsmarktinstroom. Op het WO-niveau valt met name de pluspost bij bouwkunde op. Dit betreft de instroom naar de arbeidsmarkt van postinitiële architectenopleidingen (het hoger bouwkunst onderwijs in deeltijdvorm).

Tabel 8.2

Verwachte procentuele instroom van schoolverlaters per opleidingsrichting, 1995-2000

\begin{tabular}{lccl}
\hline Opleidingsrichting & \% '95-'00 & jaarlijks \% & typering \\
\hline MBO/LLW & & & \\
civiele techniek & 27,1 & 4,9 & gemiddeld \\
bouwkunde & 16,6 & 3,1 & gemiddeld \\
landmeetkunde & 6,9 & 1,4 & laag \\
& & & \\
HBO & & & laag \\
& 10,8 & 2,1 & laag \\
civiele techniek & 12,4 & 2,4 & laag \\
bouwkunde & 11,6 & 2,2 & gemiddeld \\
landmeetkunde & & & laag \\
Wo & & & laag \\
civiele techniek & 16,1 & 3,0 & \\
bouwkunde & 12,6 & 2,4 & 1,6 \\
landmeetkunde & 8,4 & & \\
& & &
\end{tabular}

Bron: ROA

Tabel 8.2 geeft de instroom van schoolverlaters op de arbeidsmarkt voor de periode 1995-2000 in procenten van de werkzame beroepsbevolking. Hierdoor wordt de omvang van deze stroom gerelateerd aan de omvang van het betreffende marktsegment. Zowel op MBO/LLW- als WO-niveau is de instroom van civieltechnisch opgeleiden als gemiddeld getypeerd. De instroom vanuit het MBO/LLW is echter hoger dan de instroom vanuit het WO. Op HBO-niveau is er echter sprake van een lage instroom van civiel technici vanuit het onderwijs. Dit is overigens ook het geval bij bouwkunde en landmeetkunde op het $\mathrm{HBO}$. Bij het WO hebben deze twee referentiegroepen ook een lage instroom. Op MBO/LLW-niveau is alleen de instroom van landmeetkunde als laag getypeerd. 
Figuur 8.1

Arbeidsmarktinstroom vanuit het onderwijs van 1990 tot en met 1999, per opleidingsrichting
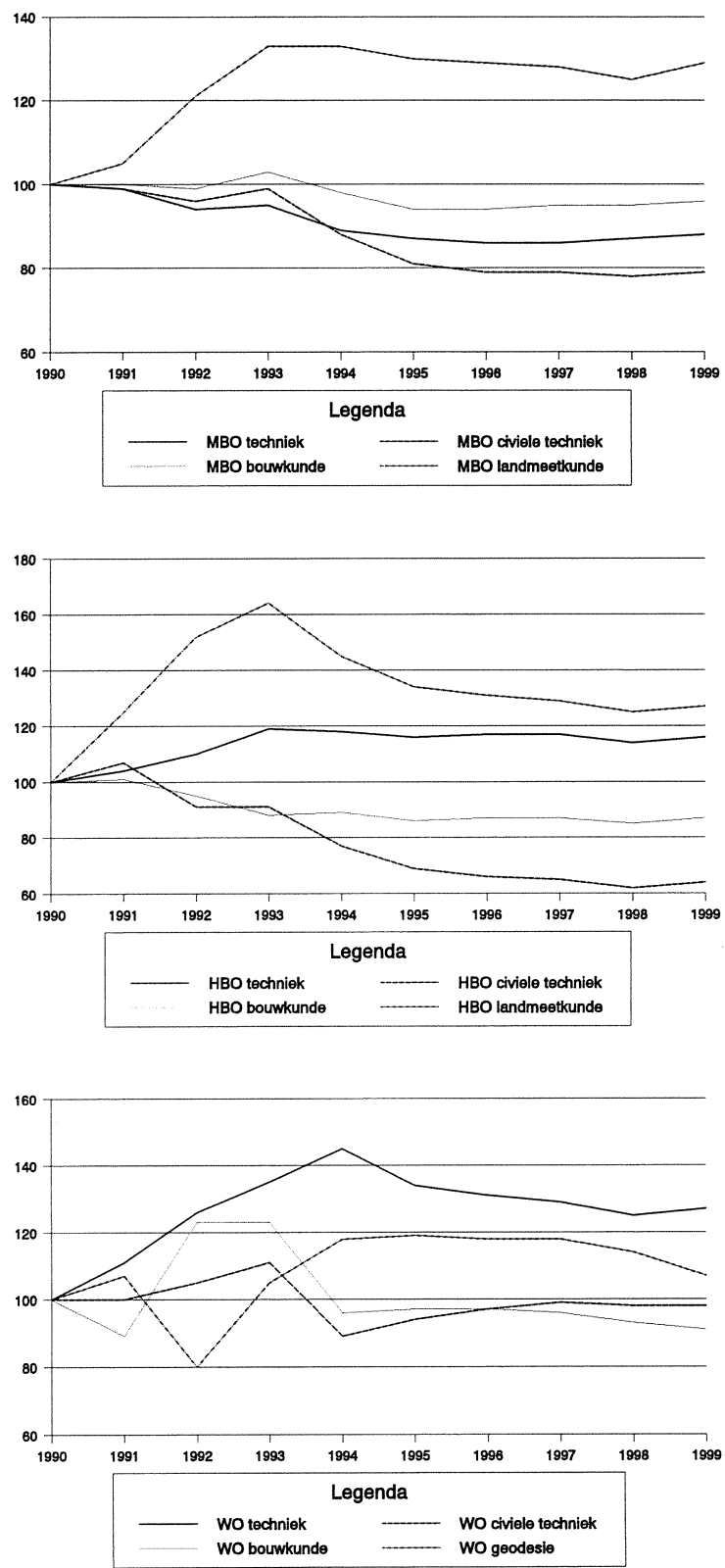

Bron: ROA

Exclusief correctie voor de gevolgen van het afschaffen van de militaire dienstplicht 


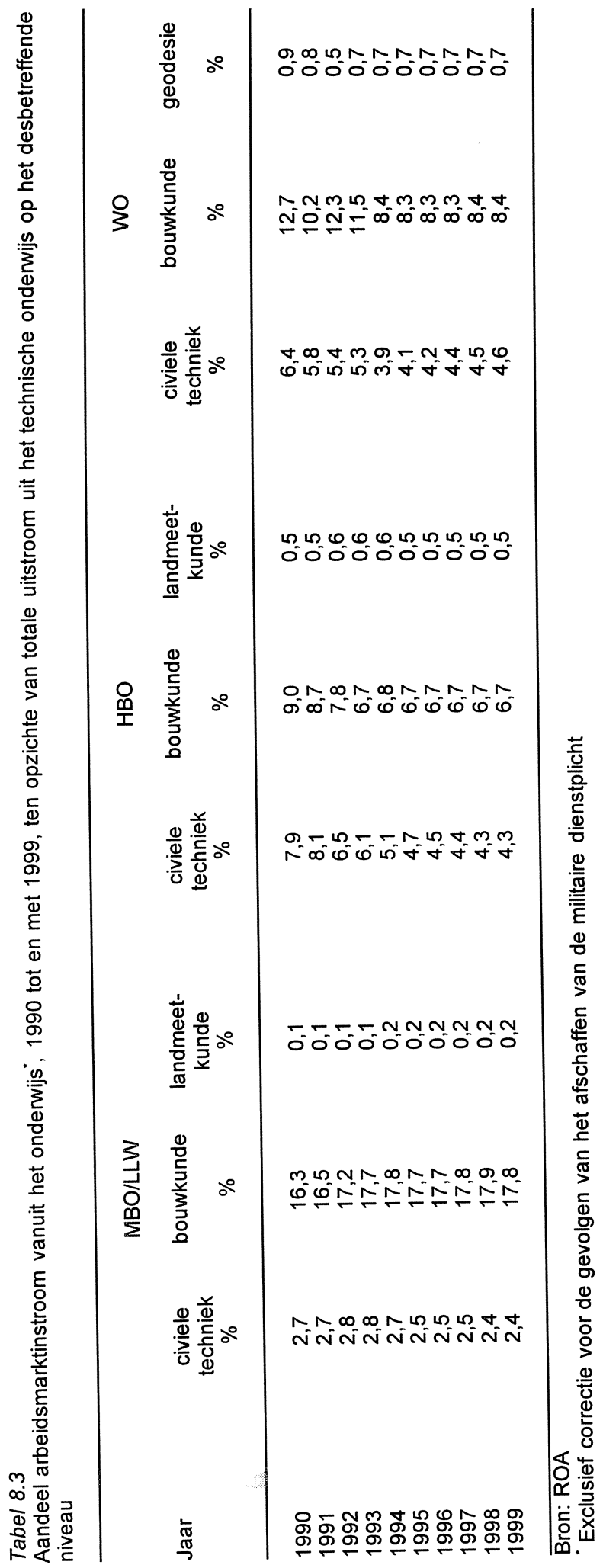


In figuur 8.1 wordt de instroom vanuit het onderwijs in een tijdsperspectief geplaatst. Hierbij is de instroom vanuit de opleidingen in 1990 op 100 gezet. De figuur laat zien dat de belangstelling (gemeten in de uitstroom) voor civiele techniek op MBO/LLW- en HBO-niveau daalt en op WO-niveau in de toekomstige periode op een lager niveau ligt dan in de historische periode. Op MBO/LLW- en HBO-niveau is de terugloop sinds 1990 vrij fors. De daling is het sterkst op HBOniveau. De arbeidsmarktinstroom van HBO'ers civiele techniek zal in 1999 slechts op $64 \%$ van de instroom in 1990 liggen. De instroom van WO'ers met een civieltechnische opleidingsachtergrond zal na een daling in 1993 weer licht gaan toenemen, maar blijt onder het niveau van de instroom in 1990. In aantallen is de instroom van WO'ers civiele techniek naar de arbeidsmarkt vrijwel constant en ligt rond de 150 personen. In het midden van de jaren tachtig lag de uitstroom bij het WO echter nog rond de 200 afgestudeerden per jaar. Ook de belangstelling voor bouwkunde loopt terug, zij het minder fors voor het MBO/LLW en HBO. Landmeetkunde geeft, mede gezien zijn kleine omvang, een wisselend beeld. In het algemeen neemt de instroom van landmeetkundigen naar de arbeidsmarkt vanaf 1990 een aantal jaren toe en neemt daarna weer af.

Van belang is echter te constateren dat op het MBO/LLW-niveau de totale arbeidsmarktinstroom van technisch opgeleiden tot 1996 (flink) terugloopt, terwijl op zowel HBO- als WO-niveau de uitstroom uit de technische opleidingen nog steeds stijgt en in de toekomst een wat wisselend beeld zal laten zien. Tabel 8.3 laat daarom het verloop zien van de uitstroom als percentage van de technische opleidingen als geheel op het desbetreffende niveau. Vanuit dit perspectief is de terugloop in de uitstroom uit de opleiding civiele techniek op MBO/LLW-niveau gematigd te noemen, maar de terugloop bij het HBO en WO zeer fors. Bij het MBO/LLW gaat tussen 1990 en $199911 \%$ van het aandeel verloren, terwijl bij het WO de terugloop $28 \%$ is en bij het HBO zelfs bijna sprake is van een halvering. 


\section{Vraag en aanbod 1995-2000}

De arbeidsmarktsituatie van een opleidingstype wordt bepaald door vraag en aanbod tegenover elkaar te stellen. In dit hoofdstuk wordt voor civiele techniek op de drie onderscheiden opleidingsniveaus de balans opgemaakt. Op grond hiervan wordt de Indicator Toekomstige kans op Knelpunten in de Personeelsvoorziening (ITKP) berekend. Naast de in de vorige hoofdstukken besproken uitbreidingsvraag, vervangingsvraag en de instroom van schoolverlaters wordt hierbij ook rekening gehouden met de werklozen die aan het begin van de prognoseperiode aanwezig zijn. Hierbij worden alleen de kortdurig werklozen meegerekend, omdat verondersteld wordt dat degenen die reeds langer dan een jaar werkloos zijn geen kans meer maken op een baan waarvoor de opleiding civiele techniek wordt vereist.

Daarnaast wordt bij de ITKP ook rekening gehouden met de zogenaamde substitutievraag. Zoals reeds werd opgemerkt is het beroependomein van civiele techniek geen afgesloten segment. Binnen de GWW-sector wordt weliswaar voor technische functies vrijwel exclusief een civiel-technische opleiding gevraagd, maar ook moet rekening gehouden worden met het feit dat een behoorlijk deel van de civieltechnisch opgeleiden buiten deze branche werkzaam is. Voor civiele techniek is deze niet-vakspecifieke vraag overigens kleiner dan voor andere technische opleidingen. Met de ontwikkeling van de vraag in dit niet GWW-segment is reeds rekening gehouden in de uitbreidingsvraag-prognoses. Hierbij is verondersteld dat civiele techniek een op grond van de huidige marktpositie in deze branches c.q. beroepen, evenredig deel van deze niet-vakspecifieke vraag zal krijgen. Als er bij andere opleidingstypen echter tekorten of overschotten zullen zijn, kan verwacht worden dat deze verhoudingen zullen verschuiven. Met name op HBO- en WOniveau zal dit de komende jaren het geval zijn. Omdat er voor een aantal technische opleidingen op HBO- en WO-niveau aanbodtekorten worden verwacht, dient er rekening mee gehouden te worden dat de aantrekkingskracht van bijvoorbeeld het beroep programmeur of systeemontwerper toe zal nemen. Er wordt in dat geval gesproken van een substitutievraag vanuit andere opleidingstypen die niet in hun vraag kunnen voldoen.

De ITKP geeft de verhouding tussen aanbod en vraag, waarbij aan beide kanten van de deling de werkzame personen aan het begin van de prognoseperiode worden meegenomen. Hoe kleiner de indicator des te groter zijn de verwachte knelpunten in de personeelsvoorziening. Als de indicator kleiner of gelijk is aan 0,95 , wordt gesproken van een grote kans op knelpunten. Tussen 0,95 en de evenwichtssituatie 1,00 is de kans op knelpunten redelijk groot. Tussen 1,00 en 1,05 wordt de kans op knelpunten als klein getypeerd en als de indicator hoger is dan 1,05 dan is er sprake van een zeer kleine kans op knelpunten. 
Tabel 9.1 laat zien dat, ongeacht of er rekening wordt gehouden met de verwachte substitutievraag, er op MBO/LLW-niveau sprake is van een zeer kleine kans op knelpunten in de personeelsvoorziening voor civiel technici, terwijl deze op HBOen WO-niveau groot is.

Tabel 9.1

Arbeidsmarktsituatie voor civiele techniek per opleidingsniveau, 1995-2000

\begin{tabular}{lccc}
\hline & $\begin{array}{c}\text { MBO/LLW } \\
\text { civiele techniek } \\
\%\end{array}$ & $\begin{array}{c}\text { HBO } \\
\text { civiele techniek } \\
\%\end{array}$ & $\begin{array}{c}\text { WO } \\
\text { civiele techniek } \\
\%\end{array}$ \\
\hline Werkzaam aan begin periode & 16.500 & 14.000 & 5.000 \\
Uitbreidingsvraag & 7,9 & 15,7 & 24,6 \\
Vervangingsvraag & 11,2 & 16,2 & 18,1 \\
Substitutievraag & 0,4 & 7,5 & 11,9 \\
Instroom schoolverlaters & 27,1 & 10,8 & 16,1 \\
Werkloosheid (kortdurig) & 3,6 & 1,7 & 1,0 \\
ITKP excl. substitutie & 1,10 & 0,85 & 0,82 \\
ITKP & 1,09 & 0,81 & 0,76 \\
typering kans op knelpunten & zeer klein & groot & groot
\end{tabular}

Bron: ROA

Voor het MBO/LLW is het toekomstige aanbod van civiel-technisch opgeleiden meer dan voldoende om te voorzien in de uitbreidings- en vervangingsvraag. Vooral de hoge instroom van schoolverlaters is een belangrijke oorzaak van het overschot. Voor een substantieel deel wordt de hoge instroom van civiel technici veroorzaakt door het wegvallen van de dienstplicht. Zonder dit effect zou de kans op knelpunten overigens klein zijn. De ITKP bedraagt in dat geval 1,05.

Voor het HBO is de instroom uit het civiel-technisch onderwijs juist opvallend laag. Dit aanbod van schoolverlaters is zelfs onvoldoende om alleen te voorzien in de vervangingsvraag. Dit betekent dat zelfs als de uitbreidingsvraag te optimistisch is ingeschat er knelpunten in de personeelsvoorziening voor civiel-technisch opgeleiden verwacht mogen worden. Uitgaande van de hoge verwachte uitbreidingsvraag en de verwachte substitutievraag zijn de knelpunten in de personeelsvoorziening derhalve groot.

Ook voor het wetenschappelijk onderwijs geldt dat de verwachte instroom van schoolverlaters civiele techniek onvoldoende groot is om te voorzien in alleen al de vervangingsbehoefte. De procentuele instroom is op WO-niveau weliswaar aanmerkelijk hoger dan bij het hoger beroepsonderwijs, maar ook de verwachte 
vervangingsvraag voor civiele techniek is hier groter. Daarnaast zijn bij het wetenschappelijk ondenwijs de voorspelde uitbreidingsvraag en de verwachte substitutievraag ook hoger dan bij het hoger beroepsonderwijs, zodat per saldo de ITKP lager is. Ook bij WO civiele techniek worden daarom de komende vijf jaar knelpunten in de personeelsvoorziening voorzien.

De verwachte vraagontwikkeling voor de opleidingen in de civiele techniek is redelijk homogeen verdeeld over de prognoseperiode. Daardoor zullen de verwachte knelpunten op HBO- en WO-niveau zich geleidelijk ontwikkelen. Op MBO/LLW-niveau speelt de ontwikkeling van het aanbod echter een grote rol. Met name aan het begin van de prognoseperiode zal de invloed, die het verdwijnen van de dienstplicht met zich meebrengt voelbaar zijn. Hierdoor zal het overschot aan MBO/LLW civiele techniek met name in het begin van de prognoseperiode snel oplopen. 



\section{Arbeidsmarktprognoses voor de periode $2000-2010$}

Op vergelijkbare wijze als voor de periode 1995-2000 kan ook voor de lange termijn een prognose van de arbeidsmarktsituatie van civiel-technisch opgeleiden worden gemaakt. In dit hoofdstuk worden de verwachtingen voor de periode 2000-2010 geschetst. Voor de vervangingsvraag en de instroom van schoolverlaters kan in principe dezelfde prognosemethodiek gevolgd worden als voor de middellangetermijnprognoses in de vorige hoofdstukken. De gebruikte modellen worden in dit geval voor een langere tijdsperiode doorgerekend. Uiteraard dient men zich ervan bewust te zijn dat dergelijke lange-termijnprognoses met veel meer onzekerheid omgeven zijn dan de prognoses voor de middellange termijn. Wat betreft de instroomprognoses zou de belangstelling voor de studierichting civiele techniek plotseling toe of af kunnen nemen. Voor de periode 1995-2000 zou de invloed hiervan gering zijn, omdat een groot deel van de schoolverlaters reeds in de pijplijn van het onderwijs zit. Voor de lange termijn kan dit echter wel tot grote verschuivingen aanleiding geven. Ook de prognoses voor de vervangingsvraag zullen op de lange termijn extra onzekerheden bevatten. De voorspellingen bevatten impliciet de veronderstelling dat er zich geen veranderingen voor zullen doen in de uitstroomcoëfficiënten per leeftijdsgroep. Het is echter goed denkbaar dat er zich in de loop van de tijd veranderingen voor zullen doen in de mate waarin mensen de arbeidsmarkt verlaten vanwege arbeidsongeschiktheid, maar het is ook denkbaar dat in de toekomst het tijdstip zal veranderen waarop mensen vanwege VUT of pensioen de arbeidsmarkt verlaten.

Uit een evaluatiestudie (Borghans, De Grip en Van Eijs, 1994) is echter gebleken dat de grootste onzekerheid in arbeidsmarktprognoses gelegen is in de uitbreidingsvraag. Bovendien moet voor de uitbreidingsvraagprognoses voor de periode 2000-2010 een afwijkende aanpak worden gevolgd, omdat de bedrijfssectorprognoses van het CPB zich tot de middellange termijn beperken. Voor de langere termijn heeft het CPB de scenario-studie Nederland in drievoud (CPB, 1992) gepubliceerd. In deze studie geeft het CPB een prognose van de economische ontwikkeling volgens drie scenario's: Global Shift, Balanced Growth en European Renaissance. Omdat het Global-Shift-scenario uitgaat van de gedachte dat het huidige economisch beleid wordt voortgezet - en daarom ook wel als het doormodderscenario wordt aangeduid - zijn deze prognoses als uitgangspunt voor de prognoses van de uitbreidingsvraag gekozen. Hierdoor ontstaat een beeld van de verwachte ontwikkelingen als er geen beleidsveranderingen plaatsvinden. In Balanced Growth wordt verondersteld dat alle markten in 2015 in evenwicht zijn en dat dus alle spanningen in de economie door een marktconform beleid langzamerhand verdwijnen, terwijl in European Renaissance een opleving van de Europese economie verondersteld wordt vanwege een verdergaande Europese integratie. Beide alternatieve scenario's 
zijn - in termen van groei - gunstiger dan het Global-Shift-scenario. Dit betekent dat vooral voor de eerste vijf jaren van de volgende eeuw de vraag naar arbeid sneller zal stijgen. Daarna is deze groei lager dan bij het Global-Shift-scenario, maar per saldo blijft de groei over de gehele periode bij de twee alternatieve scenario's groter.

Het Global-Shift-scenario gaat ervan uit dat, terwijl er op wereldschaal sprake is van een zeer snelle technologische ontwikkeling, er binnen Europa in eerste instantie geen verdere liberalisering van de internationale handel plaatsvindt. Hierdoor stagneert de economische groei in Europa en verschuift het economisch zwaartepunt naar Oost-Azië en de Verenigde Staten. Nederland specialiseert zich in activiteiten die naar verwachting op langere termijn slechts een zeer beperkte groei zullen kennen. Om en nabij het jaar 2005 dringt echter het besef door dat de Nederlandse economie moet worden geherstructureerd in de richting van hoogwaardiger en meer kennisintensieve marktsegmenten.

Het CPB voorziet vanuit dit scenario een jaarlijkse groei van de vervoerssector van $2,4 \%$ voor 2005 en $3,3 \%$ daarna. Voor het openbaar nut wordt voor 2005 0,3\% groei verwacht en na 2005 0,6\%. Omdat op grond van Corten en Nyman (1995) verondersteld kan worden dat in $200034 \%$ van de activiteiten in de GWW-sector aan vervoer gerelateerd zijn en de overige activiteiten met het openbaar nut te maken hebben, worden deze groeicijfers volgens deze verhouding opgelegd aan de GWW-sector gerelateerde beroepen. Ook van bijvoorbeeld de overheidsberoepen wordt verondersteld dat deze in gelijke mate mee zullen groeien met de omvang van de sector. Voor de overige beroepen waarin civiel-technisch opgeleiden werkzaam zijn, zoals onderwijzer of programmeur, wordt de gemiddelde groei van de vraag naar arbeid voor de gehele economie opgelegd.

Binnen de GWW-sector moet overigens nog rekening gehouden worden met de groei van de arbeidsproduktiviteit. Het CPB verwacht in het Global-Shift-scenario een toename van de arbeidsproduktiviteit in de bouw van $0,5 \%$ per jaar tot het jaar 2005 en daarna van jaarlijks 1,8\%. Verondersteld kan worden dat deze produktiviteitsgroei vooral ontstaat door een verschuiving van laag- naar hooggeschoold werk. Daarom wordt aangenomen dat de produktiviteitsstijging volledig door zal werken op MBO/LLW-niveau, voor de helft op het HBO-niveau en dat de vraag naar WO'ers gelijk op zal lopen met de produktiviteitsstijging. 
Tabel 10.1

Indicatie arbeidsmarktsituatie voor MBO/LLW civiele techniek, 2000-2010

\begin{tabular}{lccc}
\hline & $\begin{array}{c}2000-2005 \\
\%\end{array}$ & $\begin{array}{c}2005-2010 \\
\%\end{array}$ & $\begin{array}{c}2000-2010 \\
\%\end{array}$ \\
\hline Werkzaam aan begin periode & 18.000 & 17.600 & 18.000 \\
Uitbreidingsvraag & $-2,1$ & 6,0 & 3,8 \\
Vervangingsvraag & 14,2 & 17,1 & 30,9 \\
Instroom schoolverlaters & 19,6 & 19,2 & 38,4 \\
ITKP & 1,11 & 1,01 & 1,06 \\
typering kans op knelpunten & zeer klein & klein & zeer klein \\
bij ongewijzigd beleid & & &
\end{tabular}

Bron: ROA

In tabel 10.1 worden de verwachte ontwikkelingen op de arbeidsmarkt voor MBO/LLW civiele techniek voor de periode 2000-2010 weergegeven. De tabel laat zien dat het Global-Shift-scenario voor het MBO/LLW leidt tot een daling van de vraag tussen 2000 en 2005. Daarna trekt de vraag naar MBO/LLW civiele techniek weer aan. Daarnaast zal de vervangingsvraag snel oplopen tot $17,1 \%$ in de periode 2005-2010. Tegenover de vraag staat een blijvend hoge uitstroom uit het civiel-technisch onderwijs. Deze ontwikkelingen betekenen dat de Indicator Toekomstige kans op Knelpunten in de Personeelsvoorziening (ITKP) voor de periode 2000-2005 vrij hoog is, zodat tot 2005 de kans op knelpunten voor civieltechnisch opgeleiden op MBO/LLW-niveau zeer klein is. Na 2005 komt de verhouding tussen vraag en aanbod echter veel meer in evenwicht en komt de ITKP dicht bij 1. De kans op knelpunten blijft echter klein ${ }^{4}$. In de twee alternatieve scenario's - Balanced Growth en European Renaissance - is de verwachte uitbreidingsvraag voor MBO/LLW civiele techniek in de periode 2000-2005 aanmerkelijk hoger. In plaats van een krimp wordt dan een groei in de werkgelegenheid van respectievelijk 8,7 en 6,5\% verwacht. Dit betekent dat de ITKP zou kunnen dalen tot 1,01 en er dus vrijwel evenwicht zou kunnen komen tussen vraag en aanbod. Voor de jaren na 2005 verwachten deze scenario's echter iets minder uitbreidingsvraag, zodat daar de knelpuntenindicator hoger zou zijn en de kans op knelpunten in de personeelsvoorziening voor civiel-technisch opgeleiden op MBO/LLW-niveau juist kleiner wordt.

4. Bij de berekening van de ITKP is geen rekening gehouden met substitutievraag en is uitgegaan van een werkloosheid van $5 \%$. 
Tabel 10.2

Indicatie arbeidsmarktsituatie voor HBO civiele techniek, 2000-2010

\begin{tabular}{lccc}
\hline & $\begin{array}{c}2000-2005 \\
\%\end{array}$ & $\begin{array}{c}2005-2010 \\
\%\end{array}$ & $\begin{array}{c}2000-2010 \\
\%\end{array}$ \\
\hline Werkzaam aan begin periode & 16.100 & 16.500 & 16.100 \\
Uitbreidingsvraag & 2,1 & 8,6 & 10,9 \\
Vervangingsvraag & 17,6 & 18,2 & 36,2 \\
Instroom schoolverlaters & 9,4 & 9,8 & 19,5 \\
ITKP & 0,96 & 0,91 & 0,93 \\
typering kans op knelpunten & & & groot \\
bij ongewijzigd beleid & redelijk groot & groot & \\
\hline Bron: ROA & & &
\end{tabular}

Bron: ROA

Tabel 10.2 geeft de verwachte ontwikkelingen voor de periode $2000-2010$ op de arbeidsmarkt voor HBO civiele techniek weer. Op basis van het Global-Shiftscenario wordt voor civiele techniek op HBO-niveau aanvankelijk een kleine en daarna een iets grotere uitbreidingsvraag verwacht. Ook de vervangingsvraag blijft licht stijgen. Tegenover deze vraag naar civiel-technisch opgeleiden op HBOniveau staat een blijvend lage instroom van schoolverlaters $\mathrm{HBO}$ civiele techniek. Deze instroom schiet ruim tekort om zelfs alleen in de vervangingsvraag te voorzien. De kans op knelpunten in de personeelsvoorziening voor HBO'ers civiele techniek voor de periode $2000-2005$ is dan ook redelijk groot. Daarna wordt deze kans zelfs groot. Bij de twee alternatieve scenario's is de verwachte uitbreidingsvraag voor HBO civiele techniek nog hoger. Dit is met name het geval voor de periode 2000-2005. De kans op knelpunten in de personeelsvoorziening voor civiel-technisch opgeleiden op HBO-niveau is dan ook, bij deze meer optimistische scenario's nog groter.

Tabel 10.3 geeft ten slotte de ontwikkelingen voor WO civiele techniek voor de periode 2000-2010. Ook voor WO civiele techniek worden op basis van het GlobalShift-scenario tussen 2000 en 2010 knelpunten in de personeelsvoorziening verwacht. De instroom van afgestudeerden WO civiele techniek ligt hier weliswaar procentueel gezien hoger dan bij het hoger beroepsonderwijs, maar ook de vervangings- en uitbreidingsvraag zijn hier hoger. Ook voor het wetenschappelijk onderwijs geldt dat de verwachte instroom niet eens voldoende is om in de vervangingsbehoefte te voorzien. Verder blijken ook hier de twee alternatieve scenario's van de CPB-studie Nederland in drievoud met name voor de periode 2000-2005, maar ook voor 2005-2010, een nog hogere uitbreidingsvraag te verwachten. In dat geval zouden de verwachte knelpunten in de personeelsvoor- 
ziening voor civiel-technisch opgeleiden op WO-niveau derhalve nog groter zijn.

Tabel 10.3

Indicatie arbeidsmarktsituatie voor WO civiele techniek, 2000-2010

\begin{tabular}{lccc}
\hline & $\begin{array}{c}2000-2005 \\
\%\end{array}$ & $\begin{array}{c}2005-2010 \\
\%\end{array}$ & $\begin{array}{c}2000-2010 \\
\%\end{array}$ \\
\hline Werkzaam aan begin periode & 6.300 & 6.600 & 6.300 \\
Uitbreidingsvraag & 6,1 & 10,8 & 17,5 \\
Vervangingsvraag & 18,2 & 17,6 & 36,9 \\
Instroom schoolverlaters & 12,0 & 12,3 & 24,9 \\
ITKP & 0,94 & 0,91 & 0,93 \\
typering kans op knelpunten & groot & groot & groot \\
bij ongewijzigd beleid & & &
\end{tabular}

Bron: ROA 



\section{Aanpassingsprocessen}

In de vorige hoofdstukken zijn de verwachte ontwikkelingen van vraag en aanbod voor de periode 1995-2010 voor de opleidingsrichting civiele techniek op MBO-, HBO- en WO-niveau geschetst. Tussen vraag en aanbod kunnen de komende jaren behoorlijke discrepanties ontstaan. Een verschil tussen de vraag en het aanbod voor een bepaalde opleidingscategorie op de arbeidsmarkt betekent echter niet automatisch dat er sprake zal zijn van een even groot aantal werklozen bij een aanbodoverschot of een vergelijkbaar aantal openstaande vacatures bij een aanbodtekort. In de praktijk zullen er als gevolg van arbeidsmarktdiscrepanties aanpassingsmechanismen in werking treden die er voor zorgen dat de geconstateerde spanningen op de arbeidsmarkt een minder dramatische, maar vooral ook een minder zichtbare vorm vinden.

Wieling en Borghans (1995) constateerden dat een tekort aan schoolverlaters van een bepaald opleidingstype in het algemeen leidt tot hogere beloningen, meer kans op werk in de eigen vakrichting en op het eigen niveau, minder parttime banen en meer vaste aanstellingen. Een aanbodtekort leidt er kennelijk toe dat schoolverlaters meer keuze hebben tussen de beschikbare banen en dat werkgevers in de strijd om een geschikte werknemer te werven, hun arbeidsvoorwaarden voor deze groep gunstiger maken. Omgekeerd leidt een aanbodoverschot tot een verslechtering van de arbeidsmarktsituatie van schoolverlaters.

Dit betekent dat een kwantitatief aanbodtekort (gedeeltelijk) wordt omgezet in een kwalitatief gunstigere positie voor de schoolverlater. Hiermee is uiteraard de discrepantie niet verdwenen, want dit aanpassingsproces betekent dat het voor de werkgever moeilijker wordt mensen met de desbetreffende opleidingsachtergrond te werven of dat de te werven werknemers duurder worden. Bepaalde werkgevers zullen om die reden uitkijken naar mensen met een andere opleidingsachtergrond. Dit zal met name gebeuren bij de beroepen waarvoor de specifieke opleidingsachtergrond niet cruciaal is. Op de langere termijn betekent deze gunstige arbeidsmarktsituatie mogelijk ook dat meer leerlingen voor de desbetreffende opleidingsrichting zullen kiezen. Zowel vraag als aanbod kunnen dus reageren op de geconstateerde arbeidsmarktdiscrepantie.

In dit hoofdstuk wordt globaal ingegaan op enkele aspecten die een indicatie kunnen geven voor de ruimte die de arbeidsmarkt voor (civiel) technici biedt om zich aan te passen aan de geconstateerde spanningen. Hierbij wordt ingegaan op de instroom van vrouwen vanuit het (civiel-)technisch onderwijs, de belangstelling van de jeugd voor een technische opleiding en het percentage technisch opgeleiden dat gekozen heeft voor civiele techniek. 
Vrouwen in civiele techniek

Een mogelijke oorzaak van het lage aanbod van civiel-technisch opgeleiden is het lage percentage vrouwen dat deze opleidingsrichting heeft gevolgd. In tabel 2.2 werd reeds aangegeven dat van de civiel-technisch opgeleiden in de gehele werkzame beroepsbevolking slechts enkele procenten vrouw zijn. Deze, ook vergeleken met andere richtingen binnen de techniek, lage belangstelling van vrouwen zou wellicht uitzicht kunnen bieden op een verhoging van de instroom. Tabel 11.1 laat zien dat de man-vrouw-verhouding de laatste tijd al behoorlijk veranderd is. Onder schoolverlaters is het aandeel van vrouwen veel groter dan voor de gehele werkzame beroepsbevolking. Van de schoolverlaters van technische MBO-opleidingen is $18 \%$ vrouw, terwijl dit percentage op HBO-niveau $15 \%$ bedraagt. In dat opzicht is de belangstelling onder vrouwen voor $\mathrm{HBO}$ civiele techniek op peil. Voor het MBO is de interesse voor civiele techniek onder meisjes echter vrijwel nihil. Voor het WO is het niet mogelijk een vergelijking te maken met de belangstelling van vrouwen voor het totaal van technische studierichtingen. De interesse van vrouwen lijkt echter klein te zijn voor deze academische opleidingsrichting. De cijfers van het KIvl bevestigen dit. Vrouwen blijken op WO-niveau met name te kiezen voor bouwkunde. Deze cijfers geven echter niet aan of deze verhouding ook nog bij de huidige generatie schoolverlaters actueel is.

Tabel 11.1

Percentage vrouwelijke werkzame schoolverlaters, TU Delft civiel technici" en TU-ingenieurs" per opleidingsrichting, 1994

\begin{tabular}{|c|c|c|}
\hline Opleidingsrichting & $\%$ & typering \\
\hline $\begin{array}{l}\text { MBO civiele techniek } \\
\text { MBO bouwkunde } \\
\text { MBO landmeetkunde }\end{array}$ & $\begin{array}{r}0 \\
17 \\
.\end{array}$ & $\begin{array}{l}\text { erg laag } \\
\text { laag } \\
\text { erg laag }\end{array}$ \\
\hline $\begin{array}{l}\text { HBO civiele techniek } \\
\text { w.v. verkeerskunde } \\
\text { weg- en waterbouwkunde } \\
\text { HBO bouwkunde }\end{array}$ & $\begin{array}{l}16 \\
19 \\
15 \\
17\end{array}$ & $\begin{array}{l}\text { laag } \\
\text { laag } \\
\text { laag } \\
\text { laag }\end{array}$ \\
\hline TU Delft civiele techniek & 5 & erg laag \\
\hline $\begin{array}{l}\text { WO civiele techniek } \\
\text { WO bouwkunde } \\
\text { WO geodesie } \\
\text { WO werktuigbouwkunde } \\
\text { WO elektrotechniek/informatica }\end{array}$ & $\begin{array}{r}3 \\
18 \\
1 \\
2\end{array}$ & $\begin{array}{l}\text { erg laag } \\
\text { laag } \\
\text { - } \\
\text { erg laag } \\
\text { erg laag }\end{array}$ \\
\hline
\end{tabular}

Bron: RUBS/HBO-Monitor/ROA, TU Delft, KIvl

- najaar 1992

* 1991 
Naast de keuze van vrouwen voor een civiel-technische opleidingsrichting is ook de keuze van de jeugd voor techniek als zodanig een belangrijk aspect voor de mogelijkheden het aanbod van civiel-technisch opgeleiden in de toekomst uit te breiden. Willems en De Grip (1993) onderzochten de belangstelling van de jeugd voor techniek in het algemeen. Zij constateerden dat door het keuzeproces in het onderwijs een groot deel van de leerlingen reeds vroegtijdig de mogelijkheid van een technische beroeps- of universitaire opleiding uitsluiten. Zij spreken dan ook van de alsmaar smaller wordende 'trechter naar de techniek'.

Uit dit onderzoek blijkt dat slechts $27 \%$ van de MAVO-leerlingen, $24 \%$ van de HAVO-leerlingen en 39\% van de WWO'ers een vakkenpakket kiest dat toelating geeft tot een technische opleiding ${ }^{5}$. Op het MAVO en HAVO is ongeveer driekwart van hen man, terwijl op het WWO bijna de helft van de leerlingen met een exact vakkenpakket vrouw is.

Van deze groep leerlingen met een exact vakkenpakket kiest echter lang niet iedereen voor een technische vervolgopleiding of een technisch beroep. Tabel 11.2 geeft van deze groep de vervolgopleiding of het beroep aan en verschaft verder aanvullende informatie over de kenmerken van degenen die juist wel of juist niet voor techniek kiezen.

Het blijkt dat op alle niveaus ongeveer de helft van de leerlingen met een exact vakkenpakket, een technische vervolgopleiding of een technisch beroep kiest. Het hoogst is dit percentage voor het HAVO met $62 \%$ en het laagst voor het WWO met $43 \%$. Degenen die kiezen voor een technische richting blijken hogere studieresultaten te behalen voor de B-vakken dan de leerlingen die niet voor de techniek kiezen. Aangezien dit verschil zich ook voordoet bij de A-vakken kan echter geconcludeerd worden dat juist de betere leerlingen voor techniek kiezen. Het gaat dus niet specifiek om de leerlingen die beter zijn in B-vakken. Bij de eigen inschatting van de capaciteiten voor de B-vakken blijkt opvallend genoeg dat de groep die voor techniek wil kiezen zichzelf minder hoog aanslaat dan de leerlingen die juist niet voor een technische richting kiezen. Dit lijkt in tegenspraak met de studieresultaten van beide groepen.

5. Dat wil zeggen een vakkenpakket met zowel wiskunde als natuurkunde. 


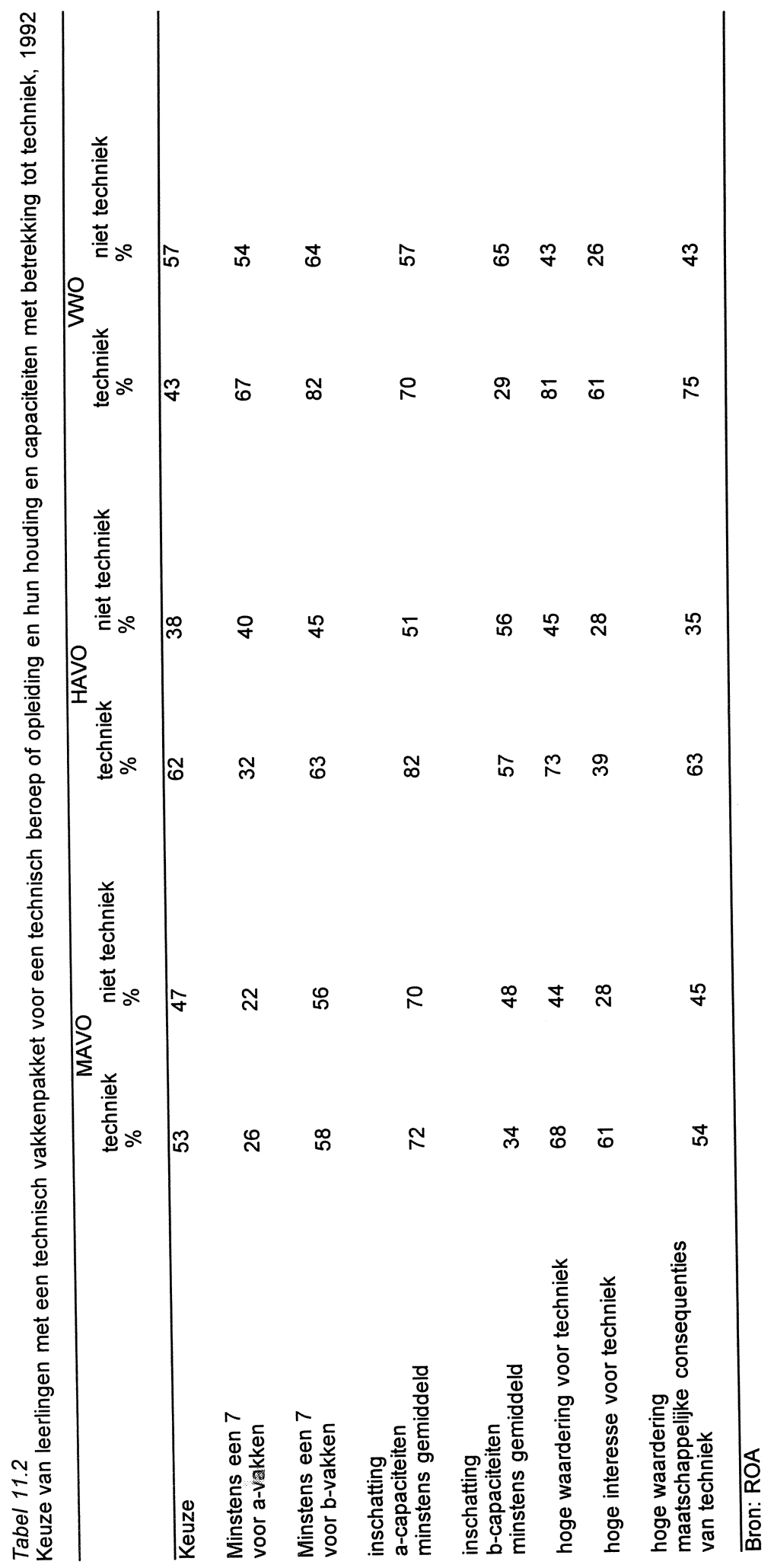


Ten slotte blijkt de groep leerlingen met een exact vakkenpakket die kiezen voor een technische vervolgopleiding of beroep wel een hogere waardering, meer interesse en een hogere waardering voor de maatschappelijke consequenties van techniek te hebben. Concluderend kan dan ook gesteld worden dat de belangrijkste verschillen tussen degenen die kiezen voor techniek en degenen die een andere richting kiezen, vooral bepaald wordt door het schoolsucces (gemeten in diplomacijfers) in het algemeen en door de persoonlijke interesse en waardering voor techniek in het bijzonder.

De keuze voor civiele techniek

Een derde aspect dat van invloed is op het aanbod van civiel-technisch opgeleiden is het feit dat de belangstelling voor civiele techniek onder studenten die een technische opleiding volgen dalende is. In tabel 8.3 werd deze relatieve terugloop in de belangstelling reeds getoond. Als de opleidingsrichting civiele techniek een uitstroom naar de arbeidsmarkt kon bewerkstelligen op basis van de verhoudingen binnen techniek van 1990, dan zou nu, in 1995 de instroom naar de arbeidsmarkt voor het HBO reeds $55 \%$ hoger liggen en zou er op WO-niveau $64 \%$ extra instromen. Rond het jaar 2000 zou dit voor MBO/LLW civiele techniek een verhoogde instroom van $13 \%$ betekenen, voor het HBO zou de verhoogde instroom $84 \%$ zijn en WO civiele techniek zou $39 \%$ extra arbeidsmarktinstroom leveren. 
...... 


\section{Conclusies}

In dit rapport is een analyse gemaakt van de arbeidsmarktontwikkelingen voor de opleiding civiele techniek op MBO-, HBO- en WO-niveau om daarmee inzicht te krijgen in de vraag of er in de periode 1995-2010 knelpunten in de personeelsvoorziening verwacht kunnen worden. Hierbij is allereerst ingegaan op de actuele arbeidsmarktsituatie. Vervolgens zijn de ontwikkelingen in vraag en aanbod in de periode 1995-2000 uitvoerig belicht en is voor diezelfde periode de balans van vraag en aanbod opgemaakt. Daarna is in meer globale termen eenzelfde vergelijking voor het eerste decennium van de volgende eeuw gemaakt. Ten slotte is in hoofdstuk 11 ingegaan op de mogelijkheid van aanpassingsprocessen die op gang kunnen komen als gevolg van de verwachte discrepanties op de arbeidsmarkt voor civiel-technisch opgeleiden. In dit slothoofdstuk worden de belangrijkste bevindingen per opleidingsniveau kort samengevat.

Voor MBO civiele techniek zijn er geen aanwijzingen dat er momenteel sprake is van tekorten in het aanbod. De arbeidsmarktpositie wijkt niet sterk af van de positie van andere technische MBO-opleidingen. Voor de periode 1995-2000 wordt dan ook een aanbodoverschot bij MBO civiele techniek verwacht. Dit komt enerzijds door de hoge uitstroom uit het onderwijs en anderzijds door de relatief lage vervangingsvraag en minder sterke uitbreidingsvraag, vergeleken met de hogere opleidingsniveaus. Verder wordt het aanbod de komende jaren aanzienlijk vergroot doordat vanwege het wegvallen van de militaire dienstplicht in deze periode in feite een extra jaargang de arbeidsmarkt opstroomt. Ook voor de periode na 2000 worden geen problemen in de personeelsvoorziening voorzien. Tussen 2000 en 2005 moet op grond van het Global-Shift-scenario van het CPB zelfs rekening gehouden worden met een lichte krimp van de vraag naar MBO civiele techniek. Daarna zal de vraag weer toenemen, maar op grond van de prognoses kan verwacht worden dat de instroom van schoolverlaters meer dan voldoende blijt om in zowel de uitbreidings- als de vervangingsvraag te voorzien.

Voor HBO civiele techniek zijn er thans wel al enkele aanwijzingen voor een aanbodtekort. Niet alle cijfers zijn echter eenduidig in dit opzicht. Voor de komende vijf jaar wordt met name verwacht dat de instroom uit het onderwijs sterk terug zal blijven lopen. Hierdoor kan het aanbod van schoolverlaters HBO civiele techniek naar verwachting niet eens voorzien in de vervangingsbehoefte, terwijl daarnaast rekening gehouden dient te worden met een aanzienlijke uitbreidingsvraag. Voor de periode na het jaar 2000 blijft dit beeld bestaan. Wanneer de instroom naar de arbeidsmarkt op dit lage niveau blijft liggen, blijft dit ook tot het jaar 2010 zorgen voor tekorten aan HBO'ers civiele techniek. 
De informatie over de actuele arbeidsmarktsituatie voor WO civiele techniek wijst, meer nog dan bij het HBO (de werkloosheid op WO-niveau ligt op een nog lager niveau dan voor het hoger beroepsonderwijs), in de richting van tekorten. Ook hier zullen naar verwachting de komende jaren tekorten blijven bestaan. De instroom van afgestudeerden WO civiele techniek naar de arbeidsmarkt is weliswaar procentueel gezien hoger dan bij het HBO, maar ook hier is deze niet voldoende om alleen al in de vervangingsbehoefte van de komende vijf jaar te kunnen voorzien. Deze vervangingsvraag is iets hoger dan in een evenwichtssituatie. De arbeidsmarktuitstroom is overigens niet dermate groot dat een tekort aan ervaren personeel gevreesd moet worden. Bovendien is de verwachte uitbreidingsvraag voor WO'ers groter dan voor HBO'ers civiele techniek. Ook voor na het jaar 2000 blijt de kans op knelpunten in de personeelsvoorziening voor WO civiele techniek groot. 


\section{Literatuurlijst}

Aartman, J.A.G., I.W. Corten, A. Kranenborg, A.L.J. Veraart, De bouwarbeidsmarkt in de periode 1993-2000, EIB, Amsterdam, 1995.

AMOA, Marktontwikkelingen 1995, Veenendaal, 1995.

Borghans, L., P. van Eijs, A. de Grip, Evaluatie arbeidsmarktprognoses naar opleiding en beroep in 1992, ROA-R-1994/4, Maastricht, 1994.

Borghans, L., H. Heijke, Forecasting the educational Structure of Occupations: a Manpower requirement approach with substitution, ROA-RM-1993/2E, Maastricht, 1993.

Borghans, L., H. Heijke, Een random-coëfficiënten-model voor het voorspellen van de beroepenstructuur van bedrifstakken, ROA-W-1994/1, Maastricht, 1994.

Borghans, L., A. de Grip, W. Smits, Beroepsmobiliteit van technisch opgeleiden, OSA-werkdocument D1, Den Haag, 1995.

Borghans, L., A. Matheeuwsen, Forecasting educational outflow per type of education, ROARM-1995/*, Maastricht, 1995 (forthcoming).

Centraal Bureau voor de Statistiek, Enquête Beroepsbevolking 1994, Voorburg/Heerlen, 1995.

Centraal Planbureau, Nederland in drievoud, een scenariostudie van de Nederlandse economie, 1990-2015, Den Haag, 1992.

Centraal Planbureau, Centraal Economisch Plan 1994, Den Haag, 1994.

Centraal Planbureau, Centraal Economisch Plan 1995, Den Haag, 1995.

Corten, I.W., A.J.N. Nijman, De grond-, water- en wegenbouw op middellange termijn, EIB, Amsterdam, 1995

EIB, De verwachtingen voor de bouwproduktie en de werkgelegenheid in 1995, Amsterdam, 1995.

Groot, P.J.M., Investeringen in grond-, water- en wegenbouwkundige werken door bedrijven, EIB, Amsterdam, 1995

KIvI, Salarisenquête TU-ingenieurs 1991, Een onderzoek naar primaire en secundaire arbeidsvoonwaarden, Den Haag, 1992.

Loo, P.J.E. van de, J. Hoevenberg, R.K.W. van der Velden, De arbeidsmarktpositie van afgestudeerden van het hoger beroepsonderwijs, HBO-Monitor 1994, HBO-Raad, Den Haag, 1995.

Matheeuwsen, A.G.M., W. Smits, E.J.T.A. Willems, Trendrapport arbeidsmarkt technisch opgeleiden, ROA-R-1994/12, Maastricht, 1994.

Ministerie van Onderwijs, Cultuur en Wetenschappen, Referentieraming 1995, Zoetermeer, 1995.

Ministerie van Onderwijs, Cultuur en Wetenschappen, WO Verdeelraming 1994, Zoetermeer, 1994.

Neut, A.C., van der, M.E. Veldhoen, J.F.M. de Jonge, De werkloosheid onder hoger opgeleiden in 1993, Research voor Beleid, Leiden, 1994.

Ramaekers, G.W.M., R.J.P. Dekker, Aansluiting opleiding-werk en arbeidsmarktpositie van civiel-ingenieurs, ROA-R-1993/3, Maastricht, 1993.

Ramaekers, G.W.M., Arbeidsmarktscanner Rijksuniversiteit Limburg, cohort '92, ROA-R1994/7, Maastricht, 1994.

Researchcentrum voor Onderwijs en Arbeidsmarkt, De arbeidsmarkt naar opleiding en beroep tot 2000, ROA-R-1995/3, Maastricht, 1995a.

Researchcentrum voor Onderwijs en Arbeidsmarkt, Statistische Bijlage, De arbeidsmarkt naar opleiding en beroep tot 2000, ROA-R-1995/3B, Maastricht, 1995b.

Researchcentrum voor Onderwijs en Arbeidsmarkt, Methodiek van het Informatiesysteem Onderwijs-Arbeidsmarkt 1995, ROA-W-1995/3, Maastricht, 1995c. 
Smoorenburg, M.S.M. van, R.K.W. van der Velden, Schoolverlaters op de arbeidsmarkt; de uitstroom en bestemming van het schooljaar 1992-1993, Stichting Landelijk Dienstverlenend Centrum voor Studie- en Beroepskeuzevoorlichting, Leeuwarden, 1995.

Wieling, M., L. Borghans, Discrepancies between Demand and Supply and Adjustment Processes on the Labour Market, ROA-RM-1995/4E, Maastricht, 1995.

Willems, E.J.T.A., A. de Grip, Toekomst in techniek?, waarde-oriëntatie, beeldvorming en keuze-intenties van jongeren, ROA-R-1993/7, Maastricht, 1993. 


\section{Appendix Indeling opleidingsrichtingen}

Tabel A.1

Technische opleidingsrichtingen CBS/ROA-gegevens en prognoses

\begin{tabular}{|c|c|}
\hline Opleidingsrichting & SOI-codes \\
\hline \multicolumn{2}{|l|}{ Middelbaar beroepsonderwijs } \\
\hline MBO technisch laboratorium & $\begin{array}{l}43100-43199 \\
43610-43619,43810-43819\end{array}$ \\
\hline $\begin{array}{l}\text { MBO/LLW bouwkunde } \\
\text { MBO/LLW civiele techniek }\end{array}$ & $\begin{array}{l}43610-43619,43810-43819 \\
\mathbf{4 3 6 2 3}, \mathbf{4 3 8 2 3}\end{array}$ \\
\hline MBO landmeetkunde & 43625,43825 \\
\hline MBO/LLW metaalkunde & $\begin{array}{l}43630-43634,43636-43639 \\
43830-43834,43836-43839\end{array}$ \\
\hline MBO/LLW fijnmechanische techniek & 43635,43835 \\
\hline MBO/LLW werktuigbouwkunde & $\begin{array}{l}43640,43642-43649 \\
43840,43842-43849\end{array}$ \\
\hline MBO/LLW motorvoertuigentechniek & 43641,43841 \\
\hline MBO/LLW elektrotechniek & $43650-43659,43850-43859$ \\
\hline MBO/LLW grafische techniek & $43663-43668,43863-43868$ \\
\hline MBO/LLW consumptieve techniek & $43676-43677,43876-43877$ \\
\hline MBO/LLW procestechniek & 43678,43878 \\
\hline MBO/LLW textiel- en ledertechniek & $43673,43685,43873,43885$ \\
\hline MBO/LLW haven en vervoer & $44100-44999$ \\
\hline \multicolumn{2}{|l|}{ Hoger beroepsonderwijs } \\
\hline HBO technisch laboratorium & $53100-53199$ \\
\hline HBO bouwkunde & $53610-53619,53810-53819$ \\
\hline HBO civiele techniek & 53623,53823 \\
\hline HBO landmeetkunde & 53625,53825 \\
\hline HBO werktuigbouwkunde & $53640-53649,53840-53849$ \\
\hline $\begin{array}{l}\text { HBO elektrotechniek en technische informatica } \\
\text { HBO haven en vervoer }\end{array}$ & $53650-53659$ \\
\hline חDD & \\
\hline \multicolumn{2}{|l|}{ Wetenschappelijk onderwijs } \\
\hline WO bouwkunde & $\begin{array}{l}63610-63619,63810-63819, \\
73618\end{array}$ \\
\hline WO civiele techniek & 63623,73623 \\
\hline WO geodesie & 63625 \\
\hline WO werktuigbouwkunde & $63640-63649,63840-63849$ \\
\hline WO elektrotechniek en technische & $63650-63659,73651-73655$ \\
\hline
\end{tabular}

De actuele arbeidsmarktgegevens en -indicatoren voor de opleidingsrichtingen zijn gebaseerd op de Enquête Beroepsbevolking 1994 (EBB) van het Centraal Bureau voor de Statistiek (CBS). De data hebben betrekking op de periode 1993-1994. De indeling van de in dit rapport onderscheiden opleidingsrichtingen is een verbijzondering van een door het ROA ontwikkelde opleidingsindeling, die is afgeleid van de classificatie die het CBS hanteert. Deze classificatie is de Standaard Onderwijs Indeling (SOI) van 1978 (editie 1993) van het CBS. Binnen deze SOl-codes is geen onderscheid te maken tussen MBO- en leerlingwezenopleidingen, zodat de gegevens over het middelbaar beroepsonderwijs uit de EBB steeds betrekking hebben op het MBO inclusief de LLW-opleidingen. De SOl-nummers van de in dit 
rapport gehanteerde opleidingstypen staan vermeld in tabel A.1.

In tabel A.2 wordt voor de opleidingsrichtingen civiele techniek en landmeetkunde/geodesie op alle niveaus een overzicht gegeven van een aantal opleidingen die tot deze opleidingsrichtingen behoren.

Tabel A.2

Opleidingen behorend tot de opleidingsrichtingen civiele techniek en landmeetkunde/geodesie

Opleidingsrichting

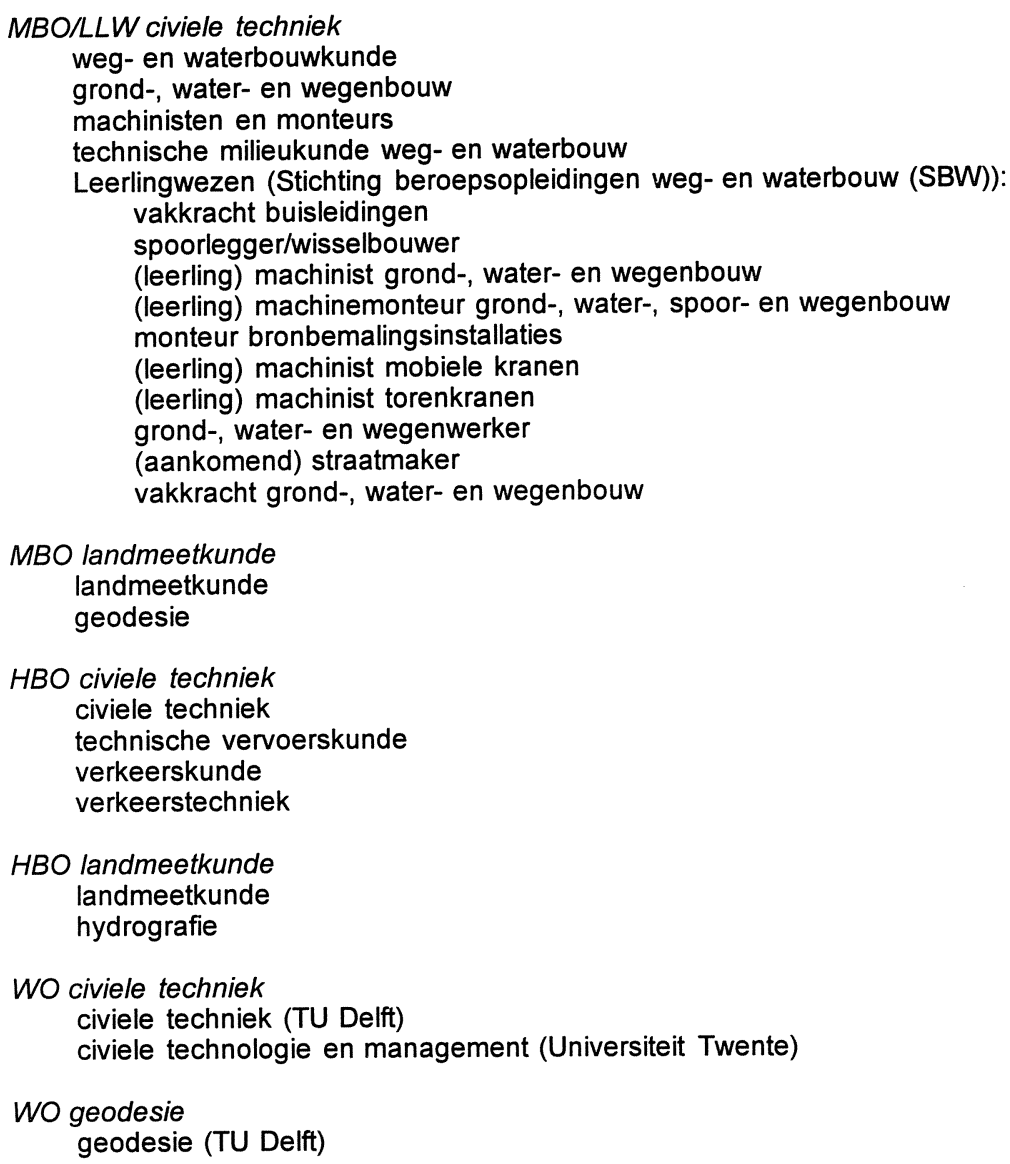

HBO landmeetkunde landmeetkunde hydrografie

WO civiele techniek civiele techniek (TU Delft) civiele technologie en management (Universiteit Twente)

WO geodesie geodesie (TU Delft)

Voor de toekomstige instroom van schoolverlaters met een civiel-technische opleidingsachtergrond is op MBO-niveau het leerlingwezen, gezien het afwijkende karakter van deze opleiding, ook apart opgenomen. Op WO-niveau is de in 1992 aan de Universiteit Twente gestartte civiel-technische studierichting civiele techno- 
logie en management buiten beschouwing gelaten. Deze opleiding sluit onvoldoende aan bij de voor Rijkswaterstaat relevante categorie WO civiele techniek.

In tabel A.3 wordt een overzicht gegeven van de onderscheiden opleidingsrichtingen binnen de grootschalige schoolverlatersenquêtes Registratie Uitstroom en Bestemming van Schoolverlaters (RUBS) en de HBO-Monitor.

Tabel A.3

Opleidingen behorend tot de opleidingsrichtingen civiele techniek en landmeetkunde/geodesie RUBS en HBO-Monitor

Opleidingsrichting

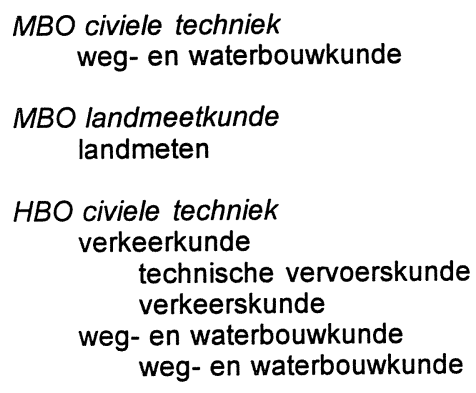

De gegevens over het middelbaar beroepsonderwijs zijn afkomstig uit RUBS 1994. Bij MBO civiele techniek zijn de meer uitvoerende opleidingen (machinist wegenbouw, wegenbouwtechniek en monteur wegenbouw) buiten beschouwing gelaten, omdat dit voor Rijkswaterstaat geen doelgroepen zijn. De gegevens over het hoger beroepsonderwijs zijn gebaseerd op de HBO-Monitor 1994. De opleidingsrichting HBO landmeetkunde is niet te onderscheiden. De opleidingsrichting HBO civiele techniek is samengesteld uit de opleidingen technische vervoerskunde, verkeerskunde en weg- en waterbouwkunde. In de tabellen in dit rapport worden steeds gegevens gepresenteerd voor deze totale groep civiele techniek, maar tevens voor de onderscheiden subgroepen verkeerskunde (technische vervoerskunde en verkeerskunde) en weg- en waterbouwkunde. 
